\title{
Do Strict Regulators Increase the Transparency of Banks?*
}

\author{
Anna M. Costello ${ }^{1}$, João Granja ${ }^{2}$, and Joseph Weber $^{3}$ \\ ${ }^{1}$ University of Michigan, Ross School of Business \\ ${ }^{2}$ University of Chicago, Booth School of Business \\ ${ }^{3}$ Massacusetts Institute of Technology, Sloan School of Management
}

November 19, 2018

\begin{abstract}
We investigate the role that regulatory strictness plays on the enforcement of financial reporting transparency in the U.S. banking industry. Using a novel measure of regulatory strictness in the enforcement of capital adequacy, we show that strict regulators are more likely to enforce restatements of banks' call reports. Further, we find that the effect of regulatory strictness on accounting enforcement is strongest in periods leading up to economic downturns and for banks with riskier asset portfolios. Overall, the results from our study indicate that regulatory oversight plays an important role in enforcing financial reporting transparency, particularly in periods leading up to economic crises. We interpret this evidence as inconsistent with the idea that strict bank regulators put significant weight on concerns about the potential destabilizing effects of accounting transparency.
\end{abstract}

JEL Codes: E58, G21, M40, M41

Keywords: Banking, Accounting Transparency, Regulation, Regulatory Enforcement, Accounting Restatements

${ }^{*}$ Accepted by Douglas Skinner. We thank Amit Seru for generously providing access to the U.S. Bank Regulatory Index dataset. We also thank Brad Badertscher, Mary Barth, Jannis Bischof, John Core, Peter Demerjian (discussant), Miguel Duro (discussant), Miguel Ferreira, John Gallemore, Michelle Hanlon, Christian Leuz, Amit Seru, Thomas Rauter, Rahul Vishishtha, Dushyantkumar Vyas (discussant), and workshop participants at Carnegie Mellon University, London Business School, MIT, Rice University, Washington University (Olin), UNC Kenan-Flagler Business School, Faculdade de Economia do Porto, Universität Mannheim, and participants of the Colorado Accounting Conference, Lisbon Accounting Conference, and Minnesota Empirical Conference for comments. Finally, we thank Suzie Noh for stellar research assistance. An Online Appendix to this paper can be downloaded at http://research.chicagobooth.edu/arc/journal-ofaccounting-research/online-supplements

This is the author manuscript accepted for publication and has undergone full peer review but has not been through the copyediting, typesetting, pagination and proofreading process, which may lead to differences between this version and the Version of Record. Please cite this article as doi: $10.1111 /$ joar.12255

This article is protected by copyright. All rights reserved. 


\section{Introduction}

According to a prominent narrative of the recent financial crisis, lax regulatory enforcement of financial reporting transparency in the banking sector was a key contributor to the buildup of risks that preceded the problems in the financial system. ${ }^{1}$ Investors, market participants, and members of the financial press alleged that banking regulators catered to the interests of the financial industry and failed to enforce financial reporting transparency. Others claimed that banking regulators loosened their enforcement of financial reporting transparency to insulate banks from market pressures that would have forced them to further cut lending and sell assets at already discounted prices (e.g. Hanson, Kashyap, and Stein (2011); Beatty and Liao (2014)). However, there is little empirical evidence about whether regulators tightened or loosened their oversight of banks' financial reporting over the last business cycle. We provide evidence on the role of regulators in enforcing financial reporting transparency before, during, and in the aftermath of the financial crisis.

We use a novel measure of regulatory strictness in the enforcement of capital adequacy to provide evidence on the relation between regulatory oversight and financial reporting transparency. ${ }^{2}$ Agarwal, Lucca, Seru, and Trebbi (2014) exploit the pre-determined rotation schedule of state and federal regulatory examinations to develop an index of the strictness of each state bank regulator. This measure captures the average difference between the confidential regulatory ratings assigned by state regulators and the rating assigned to the same bank by federal regulators. The authors document that a softer stance of state regulators relative to their federal counterparts is associated with negative outcomes, such as higher

\footnotetext{
${ }^{1}$ For examples of these arguments see "The Financial Crisis and the Role of Federal Regulators," from the Hearing Before the Committee on Oversight and Government Reform on October 23, 2008 (http://www.gpo.gov/fdsys/pkg/CHRG-110hhrg55764/html/CHRG-110hhrg55764.htm). During these hearings, Christopher Cox, then chairman of the SEC, suggested that the lack of financial reporting transparency contributed to the financial crisis by letting risks grow "in darkness."

${ }^{2}$ Throughout the paper we use the terms 'regulatory strictness' or 'strict regulator' interchangeably with the phrase 'regulatory strictness in the enforcement of capital adequacy.'
}

This article is protected by copyright. All rights reserved. 
bank failure rates and a lower likelihood of repayment of funds borrowed under the Troubled Asset Relief Program (TARP). We build on their paper under the assumption that stricter regulators are associated with better banking outcomes. Our paper asks whether strict regulators that perform well on a number of dimensions are also more likely to enforce higher reporting transparency. Conceptually, the relation between strict regulatory enforcement and financial reporting transparency is ambiguous. For example, strict state regulators may be less likely to enforce reporting transparency if they perceive that enforcing transparency could potentially destabilize sound financial institutions. Thus, it is an empirical question whether strict regulators that perform well on a number of dimensions enforce higher or lower transparency.

Our measure of regulatory enforcement of financial reporting transparency is the likelihood of regulatory restatements. Regulators audit the content of regulatory reports during on-site examinations. A restatement captures the extent to which the regulator takes actions to correct accounting mistakes, errors, and irregularities that misstate reported capital. We interpret a greater incidence of regulatory restatements as enhancing the accuracy and reliability of financial reports, thereby improving the bank's transparency. Our measure of transparency is distinct to our setting and captures the regulator's role in enforcing reliable reporting of regulatory capital. Other papers define transparency in the banking sector as disclosures that increase the precision of the public signals about banks' financial condition (e.g., Goldstein and Sapra (2014); Parlatore (2015)). ${ }^{3}$

One possible concern with using regulatory restatements as a measure of reporting transparency is that differences in restatement rates across regulators might reflect differences in the quality of financial reporting across banks rather than differences in regulators' ability, objectives, and resources devoted to enforcing transparency. Our identification strategy relies on the assumption that state and national banks operating in the same areas are subject

\footnotetext{
${ }^{3}$ In supplemental analyses we test our hypotheses using other measures of reporting transparency.
} 
to similar economic shocks and have similar business models. ${ }^{4}$ However, the regulatory enforcement of state and national banks operating in the same areas likely differs substantially. The oversight of state banks depends on the idiosyncratic characteristics of local state banking authorities, including their ability, objectives, and resources. By contrast, a single federal regulator oversees national banks and thus should not exhibit much variation in their oversight across different states. We use the incidence of accounting restatements of national banks as a baseline for the expected rate of accounting restatements of state banks located in the same regions. In doing so, we control for the role of the bank's local economic incentives in shaping reporting transparency, allowing us to better isolate the role of differences in regulatory enforcement.

We begin our empirical analysis by documenting that commercial banks are significantly more likely to have negative restatements, i.e. restatements that reduce the level of capital and retained earnings, when they face a stricter state regulator. By contrast, we do not find an association between regulatory strictness and positive restatements. This finding suggests that strict regulators induce banks to correct errors that artificially overstate regulatory capital and is consistent with the idea that regulators face an asymmetric loss function and prefer conservative recognition choices. We interpret this evidence as inconsistent with the idea that strict bank regulators put significant weight on concerns relating transparency to potential destabilizing effects. Instead, strict regulators, who are associated with better regulatory outcomes, appear to increase enforcement of reporting transparency.

Next, we explore whether the relation between regulatory strictness and our measure of reporting transparency varies over time. An important literature suggests that more informative signals could have negative consequences, especially when economic fundamentals

\footnotetext{
${ }^{4}$ Until the 1980s, different charters implied significant differences in regulatory requirements, and therefore the incentives of state banks likely differed from that of national banks. However, Blair and Kushmeider (2006) document that since the 1980s these differences disappeared; banks now mainly select their charter based on regulatory costs and regulators' accessibility. Any remaining heterogeneity in state- versus nationalbank charter should be absorbed through our fixed effects.
}

This article is protected by copyright. All rights reserved. 
are weak. Goldstein and Sapra (2014) argue that the disclosure of stress tests could increase the likelihood of panic-based bank runs. Though we use a different measure of transparency, it is possible that strict regulators limit their enforcement of restatements if they fear that such restatements have the potential to destabilize financial institutions that would otherwise be healthy (e.g. Graham, Li, and Qiu (2008)). ${ }^{5}$ On the contrary, our results indicate that strict regulators strengthen their enforcement of accounting rules, particularly in quarters that preceded the financial crisis.

Finally, we investigate whether strict regulators direct their enforcement efforts toward banks with riskier portfolios. In the event of a bank failure, potential unaccounted losses in troubled banks are borne by the deposit insurance fund (e.g. James (1991); Donovan, Frankel, and Martin (2015)). Therefore, strict regulators may have greater incentives or may allocate more resources toward riskier banks in order to reduce potential claims against this fund. We measure the riskiness of a bank using the concentration of commercial real estate (CRE) loans, consistent with Granja, Matvos, and Seru (2017) and Cole and White (2012). ${ }^{6}$ Our evidence indicates that strict bank regulators are more likely to enforce reporting transparency early on institutions with a high concentration of CRE loans.

One concern with our analyses is that our measure of restatements may not reflect greater transparency. To address this concern, we assess the robustness of our results using alternative proxies for financial reporting transparency. ${ }^{7}$ Badertscher, Burks, and Easton (2016) show that banks often amend their call reports to correct a material misstatement

\footnotetext{
${ }^{5}$ One way this could happen is that, by sending a public signal that the bank managers misstated financial reports, stakeholders could infer that the bank is troubled and punish them accordingly. This could lead to behavior causing a negative spiral including a decline in deposits, bank runs, fire sales, etc.

${ }^{6}$ Both of these papers provide evidence suggesting commercial banks that failed in the aftermath of the financial crisis had abnormally high concentrations of Commercial and Real Estate (CRE) loans.

${ }^{7}$ One possibility is that negative restatements proxy for a hidden regulatory agenda to artificially reduce regulatory capital and create hidden capital reserves. In forcing banks to understate income, regulators can force banks to cut dividends or to raise excess capital. However, a large literature documents banks' incentives to overstate the portfolio of loans and securities and capital ratios during recessions (e.g., James (1991); Hovakimian and Kane (2000) ; Skinner (2008); Huizinga and Laeven (2012); Gallemore (2013)). Thus, if there is an asymmetric incentive of managers to misstate income on the positive side, then greater transparency is likely achieved through asymmetric restatements on the negative side.
}

This article is protected by copyright. All rights reserved. 
rather than restate their call reports. We develop a measure of call report amendments and show that stricter regulators are also associated with more call report amendments. Second, we document that banks overseen by strict regulators abnormally increase their provisions for loan losses in the early stages of the financial crisis (Nicoletti (2016)), suggesting that these banks reveal potential loan losses in their portfolios in a timelier manner. Supplementing our analyses with these two additional measures helps to reinforce our inferences relating strict regulators to greater accounting transparency.

Our paper is directly related to several strands of literature. First, we contribute to the literature examining the role of public enforcement in shaping financial reporting and disclosure in the banking industry. This literature primarily uses cross-country settings to examine how regulators shape financial reporting in banks (e.g. Barth, Caprio Jr, and Levine (2004); Bischof, Daske, Elfers, and Hail (2016); Bushman and Williams (2012)). ${ }^{8}$ Other recent studies have looked at similar questions using quasi-natural variation in bank regulatory enforcement (e.g. Hirtle, Kovner, and Plosser (2016), Gopalan, Kalda, and Manela (2017), Granja (2018)). Nicoletti (2016) uses variation in regulatory strictness from Agarwal et al. (2014) to analyze the interplay of external private auditors and bank regulators in shaping financial reporting quality. Granja and Leuz (2017) exploit the extinction of the Office of Thrift Supervision to investigate the effect of stricter supervision on the supply of credit. We add to this literature by using a novel measure of regulatory strictness in the enforcement of capital adequacy to isolate the role of regulatory oversight at several stages of a financial crisis, while holding local economic incentives, state regulations and laws, and accounting standards constant.

Second, this paper is relevant to an important literature, summarized by Beatty and Liao (2014) and Acharya and Ryan (2016), that examines the determinants and consequences of

\footnotetext{
${ }^{8}$ Bertomeu and Magee (2011) model the relation between bank supervision and financial reporting and show that banks with high quality loans exert political pressure to raise financial reporting quality in order to limit discounts that occur with liquidity shocks.
} 
the properties of accounting and disclosure systems in the banking system. Much of this literature discusses the importance of the timely recognition of accounting losses in improving financial stability and access to credit. Beatty and Liao (2011) show that banks with timelier loan loss provisions have smaller contractions in bank lending during recessionary periods, and Bushman and Williams (2012) show that timelier expected loss recognition reduces excessive risk-taking. Akins, Dou, and $\mathrm{Ng}$ (2017) show that more timely loan loss recognition at the country level reduces corruption in lending. More related to our paper, Vyas (2011) finds that governance quality, regulatory investigations, and litigation pressures have an important effect on the timeliness of financial institution write-downs, and Bhat, Ryan, and Vyas (2017) document that banks that implement better credit risk models are more timely in provisioning for credit losses. We add to this important literature by documenting that bank regulators play a significant role in triggering accounting decisions that curb the overstatement of reported capital in a timely manner.

Finally, we contribute to the literature on financial restatements. Observing a financial restatement is conditional on two events: (1) the bank's propensity to misreport, and (2) the probability that the error will be detected and corrected. A main challenge in the prior literature is correctly identifying whether the observed restatement is caused by the first event or by the second event (e.g. Rice and Weber (2012); Srinivasan, Wahid, and Yu (2014)). Our empirical strategy aims to isolate the effect of detection and correction on the probability of observing a restatement. Specifically, we hold accounting standards, external incentives to misreport, and economic conditions constant and examine the role of variation in regulatory oversight on accounting restatements. In doing so, we show that bank regulators increase the probability of detection and correction, which results in a higher probability of observing a restatement.

Our results should be interpreted with a few caveats in mind. First, while we provide evidence that strict regulators, who are associated with better regulatory outcomes, increase 
transparency, we do not directly observe the effects of this increased transparency on the stability of the banking system. Thus, we leave it to future research to disentangle whether strict regulators enhance stability through transparency. Second, we cannot observe regulatory incentives, thus we cannot be certain whether strict regulators enforce reporting transparency because they are well-intentioned or for other reasons like resource availability. ${ }^{9}$ Finally, our restatement measure may not fully capture reporting transparency, though we show that our results are robust to alternative measures of transparency used in the prior literature.

Section 2 provides a background and institutional details. Section 3 discusses our research design, and Section 4 presents the data and key variables used in the empirical tests. Section 5 provides descriptive statistics of the main sample and variables used. Section 6 describes the empirical results, and Section 7 provides robustness tests that we conduct on our main results. Section 8 offers our conclusions.

\section{Background and Institutional Details}

Commercial banks that operate in the U.S. choose between a national and a state charter. The Office of the Comptroller of the Currency (OCC) supervises banks that choose a national charter, whereas local state regulators and a federal regulator (FDIC or Federal Reserve) jointly supervise banks that choose a state charter. Thus banks supervised by both federal and state regulators and banks that are supervised only by federal regulators operate side-by-side in each state. In spite of being supervised by different institutions, state and national banks face similar regulatory requirements and have similar business models (Blair and Kushmeider

\footnotetext{
${ }^{9}$ Agarwal et al. (2014) point out that there are many factors that can drive the differences in regulatory oversight including variation in local interests, variation in resources, or variation in the extent to which the regulator is captured. Some of these factors may be related to regulatory incentives and others may not; while we recognize that regulatory incentives may be one important factor that impacts banking outcomes, we do not rule out that other factors like resource availability are also important determinants of the variation in transparency that we document in this setting.
}

This article is protected by copyright. All rights reserved. 
(2006); Agarwal et al. (2014)). ${ }^{10}$

Supervisors of commercial banks rely on both off-site and on-site monitoring activities to oversee the operations of financial institutions. The periodic on-site examinations are crucial to the regulatory process. These examinations allow bank examiners to secure access to private information either by examining critical private documents or by conducting private meetings with the management of the bank.

During the interval between consecutive on-site examinations, banking regulators conduct off-site monitoring using information from financial and regulatory reports. The accounting signals from the Reports of Condition and Income (call reports) are the primary source of information regulators use to assess whether the risk profiles of banks are deteriorating and as a result, may require corrective action. The ability of the regulators to deal with the problems of distressed financial institutions in a timely manner hinges on the precision of financial information and on the quality of the internal controls. Therefore, the success of the off-site monitoring activities depends on whether regulators, auditors, and other bank governance mechanisms ensure that the financial reporting systems of banks produce early warning signals of financial distress.

When bank supervisors detect a mistake or irregularity in the regulatory reports, the bank must either file an amended call report that corrects the accounting items that were misclassified or misstated, require a restatement of prior years' financial statements, or require the bank to use the cumulative effects approach to address the misstatement (i.e. "catch-up adjustments"). ${ }^{11}$

\footnotetext{
${ }^{10}$ In addition to its functions as primary regulator of state-chartered commercial banks, the Federal Reserve is responsible for the consolidated supervision of financial institutions that are organized as bank holding companies (BHC). According to the mandate established in the Gramm-Leach-Bliley Act (GLBA), the role of the Federal Reserve is to primarily rely on the examination reports of other agencies and to assume a coordination role between several regulatory agencies that are involved in the supervision of the subsidiaries of the BHC (Eisenbach, Haughwout, Hirtle, Kovner, Lucca, and Plosser (2017)).

${ }^{11}$ According to FDIC Examination manuals, examiners play an active role in auditing the financial reporting systems and internal control procedures of banks. Gunther and Moore (2003) show that on-site supervisory exams are associated with adverse call report revisions. Their results support the idea that examiners inspect and force revisions of financial reports at their on-site inspections.
}

This article is protected by copyright. All rights reserved. 
A substantial number of accounting errors and irregularities are corrected through call report amendments. Using a proprietary dataset, Badertscher et al. (2016) find that approximately $36 \%$ of the commercial banks in their sample amend their call reports after initial submission, and $20.7 \%$ of these amendments have a non-zero impact on regulatory capital ratios. Catch-up adjustments are less frequent than call report amendments. In a catch-up adjustment, the regulator requires the bank to adjust the current period's earnings to reflect the cumulative impact of accounting errors on regulatory capital. ${ }^{12}$ According to the FDIC's call report instructions, these catch-up adjustments reflect "corrections resulting from material accounting errors that were made in prior years' Reports of Condition and Income and not corrected by the filing of an amended report for the period in which the error was made." Restatements of prior years' call reports are more visible than catch-up adjustments because SEC-registered banks must disclose those in a 8-K filing (Tan and Young, 2015). However, they are also very infrequent and only observable for the subsample of publicly-listed banks. In a sample of publicly-listed banks, (Ghosh, Jarva, and Ryan, 2017) report that only approximately $0.7 \%$ of bank-years restate prior years' restatements.

For our main analyses, we rely on catch-up restatements to measure financial reporting transparency. There are two significant advantages of using this measure. First, both private and public banks must publicly disclose catch-up restatements in quarterly call reports, whereas amended call reports are not reported publicly, and restatements of prior years' financial statements are rare and only observable for publicly-listed banks. Researchers can only infer whether a regulatory report was amended by comparing the time stamp on the last submitted call report to the 30-day statutory filing period. If the time stamp on the last submitted call report exceeds 30 days, the call report was likely amended (Badertscher et al. (2016)). The second advantage of using catch-up restatements is that financial institutions

\footnotetext{
${ }^{12} \mathrm{Ng}$ and Rusticus (2011) suggest that banks with catch-up adjustments have a higher likelihood of failure during the financial crisis.
} 
are required to discuss the cause of the restatement in the call report, which allows us to use textual analysis to parse the types of accounting problems that precipitated the catchup adjustment. This not only provides further descriptive detail of the types of problems that lead to catch-up restatements, but it also enables us to test whether strict regulatory enforcement is more associated with certain categories of restatements. ${ }^{13}$

Despite the advantages of using catch-up restatements, we recognize that if banks are more likely to use amendments to correct misstatements our main measure may only partially capture financial reporting transparency. Furthermore, Badertscher and Burks (2011) argue that catch-up adjustments are less visible and therefore less transparent than restatements of prior year's financial statements; as a result, they suggest that a higher rate of catch-up adjustments could indicate lower transparency. We address these important concerns by re-estimating our main results using a proxy of call report amendments and a measure of abnormal loan loss provisions as our dependent variables. Our results are robust to using these measures supporting the idea that strict regulators induce accounting transparency.

To assess the economic importance of our restatement measure, we search the 10-Ks of the subset of SEC-registered banks to determine whether these banks discuss the regulatory catch-up restatements. Though only $12 \%$ of the banks in our sample are public and file GAAP financial reports, we find that many of these public banks discuss regulatory catch-up adjustments in their 10-Ks. ${ }^{14}$ For example, the Heritage Commerce Corporation recorded a catch-up adjustment of $\$ 362,000$ in its 2004 fourth quarter call report related to "Accounting for Operating Leases with Scheduled Rent Increase." Their 2004 10-K states that a similar accounting error also forced the restatement of prior years' financial statements: "This material weakness resulted in restatements of the Company's financial statements for the

\footnotetext{
${ }^{13}$ Further details on the types of restatements that are in our sample are provided in Section 5 and in Table 1 , panel C. We also report the results of testing the impact of regulatory strictness on restatement type in Section 7 and in the Online Appendix.

${ }^{14}$ In untabulated analyses, we find that our main results are stronger for non-public banks whose financial statements are unlikely to be monitored by the Securities and Exchange Commission (SEC).
} 
years ended December 31, 2002 and 2003, and the first three quarters in 2004... The material weakness resulted in accounting errors related to an asset subject to a lease." In a similar case, Washington Mutual Inc. reported a regulatory catch-up adjustment of $\$ 18,000,000$ in 2003 related to the "Overstatement of the Cash Surrender Value of its Bank-Owned Life Insurance" and discussed this accounting error in its 2003 10-K stating "During the fourth quarter of 2003, the Company concluded that the inclusion of certain components...in the cash surrender value of bank-owned life insurance policies was incorrect." Washington Mutual also restated their 2002, 2001, and 2000 reports in connection with this accounting error. ${ }^{15}$ In other cases, however, the accounting error that precipitated the catch-up adjustment did not result in a restatement of the SEC financial reports. For instance, the Harleysville National Bank \& Trust Company had a catch-up adjustment in 2009 related to purchase accounting adjustments, but they did not restate their GAAP financial reports. They did, however, discuss the regulatory catch-up adjustment in their 2009 10-K. Hence, the mapping between regulatory catch-up adjustments, SEC restatements, and disclosure in 10-K filings is not always one-to-one.

Though catch-up adjustments are used less frequently than call report amendments, all of the restatements using the catch-up approach have an impact on Tier 1 capital, while only $20 \%$ of the corrections using the amended call report approach affect Tier 1 capital. The average negative impact on Tier 1 Capital for negative restatements using the catch-up method is approximately 30 basis points. Panel A of Figure 1 plots an equal probability histogram of the restatement amount as a fraction of risk-weighted assets. The histogram suggests that approximately $30 \%$ of the restatements lower Tier1 capital by more than 12 basis points. A 12 basis point decrease in regulatory capital represents $4 \%$ of the regulatory capital slack for a bank whose Tier 1 Capital Ratio is at the sample median. In Panel B of

\footnotetext{
${ }^{15}$ Other cases of accounting errors that prompted a regulatory catch-up adjustment and a restatement of prior years 10-Ks include, for instance, Wells Fargo's Auto Lease Reclassification in 2003 and Silicon Valley Bank's 2009 correction of certain gains and losses on foreign exchange contracts.
} 
Figure 1, we plot an equal probability histogram of the restatement amount as a percentage of quarterly earnings. The histogram shows that more than $60 \%$ of the negative restatements have an impact that amounts to more than $10 \%$ of quarterly earnings. Finally, in Panel $\mathrm{C}$ of Figure 1, we plot an equal probability histogram of the restatement amount as a percentage of the allowance for loan losses. The histogram shows that approximately half of the regulatory restatements represent more than $10 \%$ of the total shock absorbing capacity embedded in the allowance for loan losses of banks.

\section{$3 \quad$ Identification Strategy}

The Riegle Act of 1994 requires state and federal regulators to alternate in conducting on-site examinations of state-chartered banks. ${ }^{16}$ Using a dataset containing the results of all on-site examinations conducted by US banking regulators, Agarwal et al. (2014) measure state-level regulatory leniency by calculating the average difference in the CAMELS rating assigned to the bank by a federal regulator versus the CAMELS rating assigned to the same bank by the corresponding state regulator. A softer average stance of the state regulators relative to their federal counterparts is associated with negative outcomes (see Agarwal et al. (2014)) and suggests that the state regulator is more lenient. Because the assignment of state regulators follows a pre-determined rotation schedule, the regulatory leniency index should not be affected by the self-selection of banks to its preferred regulator.

Our empirical analyses use the state-regulatory leniency index computed in Agarwal et al. (2014). Unlike Agarwal et al. (2014), we do not have access to the proprietary dataset containing the exact dates in which federal and state regulators conduct their on-site inspection of each commercial bank operating in the U.S. banking system. Hence our measure does

\footnotetext{
${ }^{16} \mathrm{~A}$ small fraction of banks are excluded from rotations. Based on the FDIC and Federal commercial bank examination manuals only well-capitalized banks with CAMELS ratings of 1 or 2 rotate under the AEP. In addition, banks with assets above $\$ 10$ billion are excluded. We include these banks in our analysis but the results remain statistically and economically significant when we exclude those banks with total asset size above $\$ 10$ billion.
} 
not exploit the time-varying rotation of on-site inspections by state regulators. Instead, we use the average difference in state versus federal regulatory ratings, calculated for each state regulator over our sample period.

We model the likelihood of a negative restatement of bank $i$ in quarter $t$ using the following linear probability model:

$$
\operatorname{Pr}(\text { Restatement })_{i t c r}=\alpha_{c}+\phi_{t}+\psi_{r}+\beta \text { Leniency }_{c r}+\Gamma X_{i t}+\epsilon_{i t c r}
$$

where $i$ indexes the bank, $t$ indexes the time period, $c$ indexes the county location of the bank headquarters, and $r$ indexes the regulatory authority (state or federal). We use a linear probability model to allay concerns with the incidental parameters problem, though our results are qualitatively and quantitatively similar when using a conditional logit specification as we show in the Online Appendix.

The main specification includes county fixed-effects to absorb variation in the likelihood of restatement across counties, quarter fixed effects to account for general macroeconomic trends, and a regulator fixed effect to control for differences in restatements between federal and state regulators. We also employ a more rigorous specification that includes county-by-quarter fixed effects that capture time-varying county-level unobservable economic factors affecting restatements. The focus on within-county variation is important because there is substantial cross-sectional variation in economic conditions across counties that could also affect the propensity to misstate (e.g. Mian and Sufi (2009); Mian and Sufi (2010)). In addition, state regulators are more lenient in economically depressed regions (e.g. Agarwal et al. (2014)) Hence, variation in local economic shocks could simultaneously affect the banks' propensity to misstate and the leniency of state regulators, thereby distorting our results. Our empirical strategy compares whether, on average, the differences in restatement rates between state and national banks within the same county are greater in the counties of states with stricter 
state banking regulators than in states with more lenient state banking regulators. By taking differences between state and national banks within a county, we parse out the cross-county variation in economic conditions.

The main variable of interest, Leniencycr, is defined as the regulatory leniency index from Agarwal et al. (2014). It takes non-zero values when a state authority regulates the bank, and it is assigned a value of zero when federal regulators solely regulate the bank. ${ }^{17}$ Finally, $X_{i t}$ is a vector of time-varying characteristics of the commercial bank including the total assets of the bank, total deposits of the bank, percentage of residential loans, percentage of commercial real estate loans, percentage of consumer loans, fraction of loans that are classified as non-performing, liquidity ratio, and capitalization ratio. In all regressions, we cluster standard errors at the state-by-regulator level to account for any correlation in unobservables across banks that are supervised by the same regulator within a state. ${ }^{18}$

Our research design relies on the fact that, within each county and quarter, state-chartered banks operate side-by-side with national-chartered banks. State banks are regulated by state regulators that have varying degrees of regulatory leniency depending on the state where the bank is chartered, whereas national banks are regulated by federal regulators having the same leniency index regardless of the location of the bank. Since banks located in similar geographic regions are subject to local, time-varying shocks that drive uncertainty or incentives to misstate accounting numbers, these county-level economic factors are likely to affect restatement rates. By introducing fixed-effects for every quarter within each county, we remove differences in the aggregate level of restatement rates across counties and focus on within-county-quarter differences in restatement rates between state- and national-chartered

\footnotetext{
${ }^{17}$ The Agarwal et al. (2014) regulatory leniency index is only defined for state-chartered banks. The decision to assign a value of zero to federally-chartered banks is innocuous: the federal regulator fixed-effect absorbs the mean of the regulatory leniency index within the group of federally chartered banks. The federally-chartered banks are included in the analysis in order to benchmark the expected restatement rates of the state-chartered banks located in the same region.

${ }^{18}$ All results are robust to using standard errors clustered at the county-by-regulator, state-level, bank-level, or year-level. Specifications with standard errors clustered at the county-level are largely robust, though statistically weaker than those of our main specifications.
} 
banks.

One possible concern in our setting is that the commercial banks select their charter based on the perceived level of regulatory leniency. However, to generate our results, high quality banks with a lower propensity to restate would have to be more likely to select state regulators in more lenient states. We believe this is unlikely because it goes against existing evidence that banks that switch charters are more likely to fail (Rezende (2016)). We show that our results persist when we limit our sample to the banks that do not switch charters during the sample period and to banks that were created prior to 1990. Therefore, our results are unlikely to be driven by charter selection.

Another potential concern stems from the limitations of the leniency index used in the empirical analysis. Because we do not know the exact dates of the on-site examinations, it is not possible to observe whether the accounting restatements of state-chartered banks are enforced following a federal or a state supervisor on-site visit. Our results could therefore reflect the fact that the federal regulators are systematically detecting and correcting the mistakes that strict state regulators have missed. We argue this alternative explanation is unlikely for two reasons. First, Agarwal et al. (2014) suggest that their results are unlikely to stem from an implicit "good cop/bad cop" behavior in which the regulators elicit more information by having the federal regulators go "tough" and the state regulators go "easy" on state banks. Second, because the state and federal regulators exogenously rotate in their inspections of the state-regulated banks, this hypothesis would imply that restatements of state-chartered banks would be delayed relative to those of federal-chartered banks, which are solely regulated by federal regulators. Our evidence does not suggest that the restatements rates of state-chartered banks lag those of the federal-chartered banks.

Finally, we note that if commercial banks rationally anticipate greater financial reporting enforcement from strict regulators, they will optimally invest in accounting information systems to reduce the probability of a misstatement. This behavior is likely to occur if the 
expected costs associated with a possible restatement are larger than the expected benefits of misstating a regulatory report. We note, however, that if banks engage in this behavior, our coefficients would be biased downwards as state-chartered banks regulated by stricter regulators would be less likely to restate. ${ }^{19}$

\section{Data and Key Variables}

We use quarterly data covering the universe of commercial banks operating in the United States between 2001 and 2010. Our sample starts in 2001 due to the availability of data on regulatory call report restatements and ends in 2010 due to the availability of the Agarwal et al. (2014) leniency index. We exclude savings banks and credit unions from the sample because these banks submit different types of regulatory reports (Thrift Financial Report (TFR) and Credit Union call report, respectively), and they classify accounting restatements following different guidelines.

The financial characteristics of commercial banks are taken from the call reports submitted to the Federal Deposit Insurance Corporation (FDIC). The dataset contains financial characteristics for commercial banks as well as the timing of regulatory accounting restatements. We collect information on the size, capital structure, and portfolio composition for each bank, as well as the date and type of accounting restatement.

Agarwal et al. (2014) provided the data to construct the state level U.S banking regulatory index. This index captures the average relative difference in the bank regulatory CAMELS ratings assigned by each state regulator versus the CAMELS rating assigned by the federal regulator to the same banks in that state from 1996-2010.

\footnotetext{
${ }^{19}$ In robustness tests, we condition on several bank-specific measures of accounting information and internal control system quality and find that the results are unaltered, suggesting that banks are not engaging in this behavior. Results are reported in the Online Appendix.
} 


\section{Descriptive Statistics}

Figure 2 shows the percentage of commercial banks reporting negative and positive restatements over the sample period. The financial crisis of 2007 to 2009 was marked by an unprecedented number of negative restatements. From 2001 to 2006, the percentage of banks reporting negative restatements in their regulatory reports hovered around two percent, whereas during 2007 and 2008 this percentage increased substantially to approximately $4 \%$ and $10 \%$, respectively. By contrast, the percentage of commercial banks reporting positive restatements remained low and stable over the 2001 to 2010 period.

Panel A of Table 1 presents descriptive statistics of key variables used in our analysis. There are 10,524 distinct commercial banks in our sample. The average commercial bank has a regulatory leniency index of 0.076 suggesting that, on average, state regulators are more lenient than federal regulators. The state regulator of the average bank assigns a CAMELS rating that is 0.076 points higher than what would have been assigned to the same bank by a federal regulator. CAMELS ratings are assigned on a scale from 1 through 5 , thus the difference is economically meaningful; state regulators assign a better CAMELS rating than what would have been assigned to the same bank by federal regulators in 1 out of every 15 supervisory examinations.

The commercial banks report, on average, $\$ 1.1$ billion in total assets. However, our sample comprises a wide range of bank sizes with a standard deviation in total assets of $\$ 21$ billion. Seventy-five percent of the banks are state-chartered and hold a large percentage of their assets in real estate lending.

A critical element of our research approach is that national banks and state banks located in the same geographical regions have similar business models and, as a result, react similarly to the same local economic shocks. In Panel B of Table 1, we assess whether national and state-chartered banks have similar business models by comparing banks' size, portfolio 
composition, asset quality, and capitalization. The average size of a national bank is greater than that of a state bank because most systemically important financial institutions organize as national banks. However, when we exclude these large commercial banks and focus on the median and quartiles of the size distribution, national and state banks are not significantly different from each other. ${ }^{20}$ The portfolio composition and asset quality of national and state banks are very similar, suggesting that these banks operate on the same type of business models and have similar risk profiles. These findings allay concerns that the national banks are not a good benchmark for state banks.

Panel C of Table 1 provides descriptive statistics on the types of catch-up restatements. Using a short description of the nature of the restatement available in the call reports, we use textual analysis to identify five main categories of restatements: restatements due to mathematical/clerical errors; restatements due to changes in accounting principles; restatements related to audit work; restatements related to tax issues; and "other" accrual accounting related restatements. For each category, we show the frequency of restatements, the share of the restatements that are negative, and the respective magnitude of the negative restatements as a fraction of risk-weighted assets. We find that restatements related to changes in accounting principles and restatements related to taxes make up a large portion of the sample, each representing around $25 \%$ of all catch-up restatements. However, the largest category of restatements relate to "other" accrual accounting estimates, representing $38 \%$ of the sample. The types of restatements included in this final category are very dispersed such that it is difficult to further parse and analyze sub-groups within the "other" accrual accounting category. Nevertheless, in an effort to provide some additional descriptive detail on some of the restatements in this category, we develop four sub-categories within this group: restatements related to loan loss accounting estimates; restatements related to errors

\footnotetext{
${ }^{20}$ In additional robustness tests, we find that the results remain statistically and economically significant when we eliminate large financial institutions from the sample.
} 
in the classification and valuation of the securities portfolio; restatements related to the accounting for noncurrent items; and restatements related to problems with consolidation accounting. Though these sub-categories represent a small portion of the overall sample of catch-up restatements, they are the largest identifiable types of restatements within the accrual accounting restatement group. In the Online Appendix, we present several examples of each type of restatement.

\section{Regulatory strictness and reporting restatements}

\subsection{The impact of regulatory strictness on negative restatements}

We begin our empirical analysis focusing on whether regulatory leniency impacts the detection and correction of accounting irregularities in the regulatory reporting of commercial banks. If lenient regulators are less likely to enforce accounting rules, we expect banks with lenient regulators to report fewer accounting restatements. However, it is possible that regulatory leniency is unrelated to the likelihood of accounting restatements. For example, commercial banks could anticipate the increased oversight by strict regulators and devote more financial or human capital resources to improving financial reporting quality. If these additional resource allocations help to detect or prevent call report misstatements, banks with strict regulators may have a lower probability of errors or irregularities ex ante, leading to a lower probability of forced restatements ex post.

In Panel $\mathrm{A}$ of Figure 3 we sort the state-chartered banks into five quintiles based on the leniency index of their state regulator. We then plot the average likelihood of negative restatements in each quintile. Approximately $3 \%$ of the banks that are supervised by the most lenient regulators report negative restatements. By contrast, approximately $3.8 \%$ of the banks that are supervised by the strictest regulators report negative restatements. The plot is consistent with the idea that strict regulators are more likely to detect and enforce 
negative restatements.

An alternative explanation for the above pattern is that all state regulators behave alike, but commercial banks facing strict regulators make more accounting errors than banks facing lenient regulators. If this were the case, we expect to observe the same pattern in positive restatements that we do in negative restatements. Panel B of Figure 3 plots the probability of positive restatements by regulatory leniency quintile. We do not find a similar pattern for positive restatements.

In Panels $\mathrm{C}$ and $\mathrm{D}$ of Figure 3, we sort the federally-chartered banks into five quintiles based on the regulatory leniency index of their state regulator. Because federal regulators are the sole regulator of federally-chartered banks, we do not expect that a quintile sort of regulatory restatements of national banks based on the state regulatory leniency index will generate the same patterns observed in Panels A and B of Figure 3.

Panel $\mathrm{C}$ of Figure 3 indicates that there is no clear upward or downward pattern in restatements of national banks across state leniency bins, which suggests that the regulatory leniency index captures differences in state regulatory enforcement rather than omitted economic factors. Panel D of Figure 3 further reinforces these conclusions by showing no trend in the percentage of positive restatements of federally-chartered banks across state regulatory leniency bins.

In Table 2, we formally test whether regulatory leniency is related to the likelihood of negative and positive restatements. In column (1) we report results that only include the regulatory leniency index, county fixed-effects, quarter fixed-effects, and regulator-type fixed-effects. The coefficient of the regulatory leniency index is -0.053 and is economically meaningful; a one standard deviation increase in the leniency index (0.062) decreases the likelihood of restatement by 0.33 percentage points $(-0.053 \times 0.062)$. This reduction represents a $10 \%$ decrease in the likelihood of a negative restatement relative to the unconditional probability of a negative restatement of $3.2 \%$ for the entire sample. In column (2) we report 
the results including county-by-quarter fixed effects, and in columns (3) - (6) we repeat the analysis of columns (1) and (2), but we further condition on bank characteristics such as size, portfolio composition, and asset quality. Even after controlling for these additional characteristics, our main variable of interest remains statistically significant and economically similar to that reported in column (1).

The results presented in Table 2 are consistent with two broad channels. First, they are consistent with the hypothesis that stricter regulators are more likely to enforce regulatory restatements that lower the regulatory capital ratios of their regulated entities. Second, they are consistent with the idea that the entities regulated by strict state regulators have worse accounting quality and are thus more likely to restate relative to entities regulated by lenient regulators.

We examine these two explanations by re-estimating the results of columns (1) - (6) using the likelihood of a positive restatement as the dependent variable. If banks regulated by strict regulators have lower accounting quality than banks regulated by lenient regulators, they would likely also have more positive restatements. The results presented in columns (7) - (12) show that the regulatory leniency index has no statistically significant impact on the likelihood of positive restatements. This evidence is consistent with the idea that strict regulators more aggressively enforce regulatory restatements that lower banks' regulatory capital ratios.

Overall, the results reported in Table 2 and in Figure 3 suggest that stricter regulators are more likely to enforce negative restatements relative to more lenient regulators. This supports the notion that strong regulatory enforcement is more likely to curb accounting practices that result in overstated capital. The results are also inconsistent with the idea that strict regulators reduce financial reporting enforcement in response to concerns about their destabilizing effects. Nevertheless, we recognize that the results are also consistent with the joint hypothesis that lenient regulators have a lower ability to detect material errors and 
that the latent distribution of accounting errors is asymmetric because banks are more likely to overstate than to understate earnings.

\subsection{Time-series effects of regulatory strictness}

Next, we examine whether strict regulators are swifter in detecting and enforcing accounting irregularities. Regulators could have superior information about the underlying loans, securities, investments, and other assets held by the bank, and they may have detailed knowledge of the quality of these assets (e.g. Peek, Rosengren, and Tootell (1999)). Thus stricter regulators may identify early signs of economic deterioration and increase their enforcement relatively earlier. Alternatively, strict regulators may increase their oversight of banks only after the problems with the banking and housing markets were already widely exposed.

In Table 3 we formally investigate whether strict regulators enforce accounting restatements in a timely manner. To this end, we extend specification (1) and interact the regulatory leniency index with measures of past and future financial distress faced by commercial banks. Each measure is standardized for ease of interpretation. In columns (1) and (2) of Table 3 we interact the regulatory leniency index with past and future values of the average TED spread, calculated as the difference between the interest rates on interbank loans and on short-term U.S. Government debt (Matvos and Seru (2014); Greenlaw, Hatzius, Kashyap, and Shin (2008)). As shown in column (1), the effect of regulatory leniency on the likelihood of accounting restatements in the quarter is significantly larger when market conditions deteriorate in the subsequent year. By contrast, the results of column (2) suggest that strict regulators are not associated with a significant increase in the likelihood of restatements when the external capital market was distressed in the previous year. The results from columns (1) and (2) suggest that stringent state regulators are more likely to act ahead of a significant deterioration in market conditions, but are not incrementally more likely to act after deterioration in the external capital market has already occurred. The results in column 
(1) suggest that a one standard deviation increase in the future TED spread is associated with a $50 \%$ increase in the effect of regulatory leniency.

In columns (3) and (4), we replace the TED spread with a bank-specific measure of the year-on-year change in the house price index of the local market. Following Granja et al. (2017) we scale the change in the Federal Housing Finance Agency (FHFA) quarterly MSA house price index by the level of deposits of the bank in each MSA. This measure captures variation in the exposure of banks to geographic regions with severe house price declines. In column (3), we interact the regulatory leniency index with the bank exposure to the house price decline in the subsequent year. The results suggest that the effects of regulatory leniency are significantly larger when the commercial banks are exposed to house price declines in the future. A one standard deviation increase in the house price decline is associated with a $60 \%$ increase in the effect of regulatory leniency on the likelihood of negative regulatory accounting restatements. However, the results in column (4) show that the effect of regulatory leniency on restatements is not significantly different when the bank is exposed to house price declines in the previous year. Overall, our cross-sectional findings support the idea that strict regulators act before the deterioration of economic and financial conditions. Nevertheless, we acknowledge that the results from our cross-sectional partitions could also be related to other factors that are correlated with the TED spread and the house-price index.

Finally, we extend specification (1) and estimate time series effects of regulatory leniency by interacting the leniency index with dummy variables for each quarter:

$$
\operatorname{Pr}(\text { Restatement })_{i t c r}=\alpha_{c}+\phi_{t}+\psi_{r}+\sum_{t} \beta_{t} \text { Leniency }_{c r} \times Q_{\text {r }} t_{t}+\Gamma X_{i t}+\epsilon_{i t c r}
$$

Figure 4 reports the coefficients on the quarter-dummy variable interactions, along with $95 \%$ confidence intervals. The sharp impact of regulatory strictness in 2007 is consistent with the notion that strict regulators tighten their monitoring efforts early, when the first signs 
of the housing crisis became apparent. The results are less pronounced after 2008 which is consistent with the idea that even lenient regulators increased their enforcement of capital adequacy once the problems of the banking system were widely recognized. A plausible alternative explanation for the pattern in Figure 4 is that high restatement rates early in the crisis meant that there were fewer mistakes to correct later in the crisis. We note, however, that the effect of regulatory strictness on restatement rates is highest in 2007 which largely preceded the apex of restatement rates in 2008 (see Figure 2). Thus, we take some comfort that the pattern of evidence in Figure 4 is not simply an artifact of time-series variation in restatement rates themselves.

\subsection{Heterogeneity in the Time-series effects of regulatory strictness}

Next, we investigate whether the effect of regulatory leniency on restatements varies based on the bank's loan portfolio. The prior literature suggests that Commercial and Real Estate (CRE) loans were a risky asset class during the financial crisis. Granja et al. (2017) and Cole and White (2012) show that the banks that failed in the aftermath of the crisis carried a larger concentration of CRE loans relative to other types of loans. Therefore, if stricter regulators anticipate the cross-sectional variation in the portfolio risk of commercial banks, we would expect the effect of regulatory leniency on restatements to be more pronounced in the pre-crisis period for banks with a high concentration of CRE loans.

To provide evidence on the heterogeneity in the timeliness of regulatory effectiveness, we extend specification (1) and estimate the effect of regulatory leniency on restatements in each quarter for banks with a high CRE concentration and for banks with a low CRE concentration. Figure 5a reports the coefficients on the quarter-dummy variables, along with $95 \%$ confidence intervals, for banks with a high concentration of CRE loans (above the median). Consistent with the idea that stringent regulators act more swiftly in banks that are more likely to be troubled, we find that the relation between regulatory quality and 
the enforcement of reporting transparency is strongest in quarters 1-3 of 2007. The effects of regulatory leniency are statistically indistinguishable from zero in the early part of the sample as well as during the peak of the financial crisis.

In Figure 5b, we plot the coefficients on the quarter-dummy variables for banks with a low concentration of CRE loans. In contrast to the results in Figure 5a, the effects of regulatory leniency on restatements is indistinguishable from zero both before the financial crisis and during the peak of the financial crisis. There is some evidence that the relation between regulatory oversight and restatements is stronger in the second quarter of 2010, well after the effects of the financial crisis were largely known. Overall, the evidence in Figures 5a and 5b suggests that stricter regulators were swifter in enforcing financial reporting rules for banks with higher concentrations of CRE loans.

\section{Robustness}

\subsection{Alternative dependent variables}

One possible concern with our results is that our dependent variable does not capture and measure the concept of reporting transparency either because the regulatory restatements are less transparent than other amendments (Badertscher and Burks (2011)) or because these restatements represent overzealousness of the regulator (e.g. Berger, Kyle, and Scalise (2001)). We address this concern by replacing our dependent variable with two alternative measures of transparency. First, we study whether regulatory strictness impacts loan loss provisions (e.g., Beck and Narayanamoorthy (2013); Nicoletti (2016)) by estimating the following linear regression:

$$
L L P_{i t c r}=\alpha_{c}+\phi_{t}+\psi_{r}+\sum_{t} \beta_{t} \text { Leniency }_{c r} \times Q r t_{t}+\sum_{s=-4}^{4} C O_{i+s}+\Gamma X_{i t}+\epsilon_{i t c r}
$$


where LLP represents the quarterly loan loss provisions of banks scaled by total assets, $\alpha_{c}$ and $\phi_{t}$ are dummy variables that capture time-varying and county-level unobservable economic factors, and $\psi_{r}$ controls for differences in the aggregate loan loss provisions between federal and state regulators.

The main variable of interest is Leniency $_{c r} \times$ Qrt $_{t}$, which is defined as the interaction between the regulatory leniency index and indicator variables for each quarter. $C O_{i+s}$ represents a series of lead and lag values of the ratio of loan charge-offs to total assets. Finally, $X_{i t}$ is a vector of time-varying characteristics of the bank and includes the total assets of the bank, total deposits of the bank, percentage of residential loans, percentage of CRE loans, percentage of consumer loans, liquidity and capital ratios. ${ }^{21}$

In Figure 6, we plot the time-series evolution of the coefficients $\beta_{t}$. Following the third quarter of 2007, regulatory leniency is associated with lower loan loss provisions. The relation then becomes insignificant and reverses in the last quarter of 2010. These results are consistent with the idea that strict regulators enforced greater loan loss provisions in 2007, when events indicated potential impairments in banks' loan portfolios. Financial institutions with more lenient regulators catch up with loan loss provisioning in the last quarters of 2010, only after the events of the financial crisis largely subside and markets start recovering. The results reinforce the idea that strict regulators enforced recognition of accounting deficiencies and reporting transparency in a timelier fashion. ${ }^{22}$

Second, we re-estimate our results using an alternative dependent variable that captures the likelihood that banking regulators required an amendment to the call report (Badertscher et al. (2016)). To determine whether a call report was amended we focus on whether the

\footnotetext{
${ }^{21}$ We trim the loan loss provision and charge-off variables at the 2.5 th percentile to avoid the effect of spurious outliers. The standard errors of some coefficients become slightly smaller as a result of this option but the cyclical pattern of the main coefficients as well as their statistical significance at the peak and trough of series are unaltered.

${ }^{22}$ Using loan loss provision timeliness as the dependent variable, Nicoletti (2016) shows that over a different sample period, stricter regulators are also associated with more timely provisions.
} 
time stamp on the last call report submitted exceeds the 30-day statutory filing period, which is a necessary condition to identify an amendment. ${ }^{23}$ We characterize call reports as amended if the final time stamp exceeds the 30-day statutory filing period by more than 15 days. We choose 15 days because Badertscher et al. (2016) find that the median number of days between original and restated report is 18 days. By focusing on amendments after a fifteen-day window, we increase the likelihood that they result from the action of banking regulators and private auditors.

We present the results of this analysis in Table 4. In columns (1) and (2) we show that strict regulators are associated with a greater likelihood of regulatory amendments. A one standard deviation increase in the regulatory leniency index reduces the likelihood of call report amendment by 0.6 percentage points. In columns (3) and (4) we require that the time stamp on the call report exceeds the 30-day statutory filing period by more than 45 days. When we use this stricter threshold, the results remain economically significant but they lose statistical significance in the specification of column (4).

One potential concern with the above analysis is that we are classifying late call reports as amendments. Therefore, our results might suggest that banks operating under the jurisdiction of strict banking regulators are more likely to file a late call report. We find this explanation unlikely. Badertscher et al. (2016) find that $92 \%$ of their observations file an initial version of their call report within the first five days after the statutory limit. We find that the last time stamp on $25 \%$ of the call reports on our sample exceed the 30-day statutory limit by two weeks. Together, these findings provide comfort that we are classifying amendments correctly. Moreover, Agarwal et al. (2014) show that regulatory strictness leads to better bank performance, which suggests that strictly regulated banks are less likely to file a late call report.

\footnotetext{
${ }^{23}$ Badertscher et al. (2016) developed a proprietary database of call report amendments. Since we do not have access to this database, we use this alternative approach to determine whether call reports were likely to be amended.
} 


\subsection{The impact of regulatory strictness by type of restatement}

In equilibrium, the threat of a stricter regulator could induce both bank managers and their auditors to initiate more restatements (e.g. Corona and Randhawa (2017)). While we do not directly observe who required the restatements, we use the description of the restatements in the call reports as a falsification exercise; we do not expect our regulatory leniency index to explain restatements that are unlikely to be enforced by banking regulators.

Our results, reported in the Online Appendix, indicate that there is no effect of regulatory leniency on restatements due to simple clerical errors, accounting principles, or related to taxes. However, we do find that stricter regulators are more likely to impose restatements related to the accounting for economic transactions. The results corroborate our claims that regulatory strictness drives restatements.

\subsection{Variation in accounting quality}

Our objective in this paper is to capture the increased probability that a strict regulator will detect and correct an error, rather than to capture variation in the bank's propensity to misreport. While our fixed effect structure controls for much of the potential unobserved variation in underlying incentives that affect reporting quality, we supplement our tests by controlling for the bank's underlying accounting quality. First, we use loan loss provision timeliness as in Beatty and Liao (2011). Second, we control for the level of audit intensity performed for the bank by external auditors. The results, reported in the Online Appendix, show that both the magnitude and statistical significance of the leniency index remains unchanged even after controlling for these measures of accounting quality. This provides further assurance that our results are attributable to variation in regulatory leniency. 


\subsection{Regulator selection}

A final concern with our results is that they might be driven by commercial banks that select their charter-authority according to their perceived level of regulatory leniency. We limit our sample to the banks that have not switched charters during the sample period, and we exclude banks that were created after 1990 to mitigate the concern of bank self-selection. The results, reported in the Online Appendix, show that the regulatory leniency index continues to load in the predicted manner.

\section{Conclusion}

We explore a new measure of the leniency of state regulators in order to examine whether the rigor of regulatory enforcement is associated with predictable variation in financial reporting outcomes. The results of this analysis inform our understanding of the effects of regulatory enforcement on the quality of banks' financial reporting. Specifically, we find that lenient regulators are less likely to enforce the restatement of accounting irregularities and are less timely in correcting regulatory accounting restatements in response to the deterioration in economic conditions. These findings suggest that regulators play an important role in overseeing financial reporting outcomes of banks, particularly in periods leading up to a financial crisis.

Overall, our results are likely to be of interest to both academics and policy makers. Our paper adds to the literature on regulation, suggesting that regulatory leniency leads to reduced disclosure quality. These results are likely to be useful to policymakers as they debate the causes and consequences of the recent financial crisis. 


\section{References}

ACharya, V. V. And S. G. RyAn (2016): "Banks' financial reporting and financial system stability," Journal of Accounting Research, 54, 277-340.

Agarwal, S., D. Lucca, A. Seru, And F. Trebbi (2014): "Inconsistent regulators: Evidence from banking," The Quarterly Journal of Economics, 129, 889-938.

Akins, B., Y. Dou, And J. NG (2017): "Corruption in bank lending: The role of timely loan loss recognition," Journal of Accounting and Economics, 63, 454-478.

Badertscher, B. A. And J. J. Burks (2011): "Accounting restatements and the timeliness of disclosures," Accounting Horizons, 25, 609-629.

Badertscher, B. A., J. J. Burks, And P. D. Easton (2016): "Day 30: The tacit quarterly information event in the banking industry," Unpublished Working Paper.

Barth, J. R., G. Caprio JR, And R. Levine (2004): "Bank regulation and supervision: what works best?" Journal of Financial intermediation, 13, 205-248.

BeAtTy, A. AND S. LiAo (2011): "Do delays in expected loss recognition affect banks' willingness to lend?" Journal of accounting and economics, 52, 1-20.

(2014): "Financial accounting in the banking industry: A review of the empirical literature," Journal of Accounting and Economics, 58, 339-383.

Beck, P. J. and G. S. Narayanamoorthy (2013): "Did the SEC impact banks' loan loss reserve policies and their informativeness?" Journal of Accounting and Economics, 56, $42-65$.

Berger, A. N., M. K. Kyle, And J. M. ScAlise (2001): "Did US bank supervisors get tougher during the credit crunch? Did they get easier during the banking boom? Did it matter to bank lending?" in Prudential supervision: What works and what doesn't, University of Chicago Press, 301-356.

Bertomeu, J. And R. P. Magee (2011): "From low-quality reporting to financial crises: Politics of disclosure regulation along the economic cycle," Journal of Accounting and Economics, 52, 209-227.

Bhat, G., S. Ryan, And D. Vyas (2017): "The Implications of Credit Risk Modeling for Banks' Loan Loss Provisions and Loan-Origination Procyclicality," Unpublished Working Paper.

Bischof, J., H. DAske, F. Elfers, And L. Hail (2016): "A tale of two regulators: risk disclosures, liquidity, and enforcement in the banking sector," Unpublished Working Paper.

Blair, C. E. And R. M. Kushmeider (2006): "Challenges to the dual banking system: The funding of bank supervision," FDIC Banking Rev., 18, 1. 
Bushman, R. M. And C. D. Williams (2012): "Accounting discretion, loan loss provisioning, and discipline of banks' risk-taking," Journal of Accounting and Economics, 54, 1-18.

Cole, R. A. And L. J. White (2012): "Déjà vu all over again: The causes of US commercial bank failures this time around," Journal of Financial Services Research, 42, 5-29.

Corona, C. And R. S. Randhawa (2017): "The value of confession: Admitting mistakes to build reputation," The Accounting Review, 93, 133-161.

Donovan, J., R. M. Frankel, And X. Martin (2015): "Accounting conservatism and creditor recovery rate," The Accounting Review, 90, 2267-2303.

Eisenbach, T. M., A. Haughwout, B. Hirtle, A. Kovner, D. O. Lucca, And M. C. Plosser (2017): "Supervising large, complex financial institutions: What do supervisors do?" Federal Reserve Bank of New York Staff Report 729.

Gallemore, J. (2013): "Does bank opacity enable regulatory forbearance," Unpublished Working Paper.

Ghosh, A. A., H. Jarva, And S. G. Ryan (2017): "Do Bank Regulation and Supervision Displace Bank Auditing?" .

Goldstein, I. And H. SApra (2014): "Should banks' stress test results be disclosed? An analysis of the costs and benefits," Foundations and Trends in Finance, 8, 1-54.

Gopalan, Y., A. Kalda, And A. Manela (2017): "Hub-and-Spoke Regulation and Bank Leverage," Unpublished Working Paper.

Graham, J. R., S. Li, AND J. QIU (2008): "Corporate misreporting and bank loan contracting," Journal of Financial Economics, 89, 44-61.

GranjA, J. (2018): "Disclosure regulation in the commercial banking industry: lessons from the national banking era," Journal of Accounting Research, 56, 173-216.

Granja, J. And C. Leuz (2017): "The Death of a Regulator: Strict Supervision, Bank Lending and Business Activity," Tech. rep., National Bureau of Economic Research.

Granja, J., G. Matvos, And A. Seru (2017): "Selling failed banks," The Journal of Finance, 72, 1723-1784.

Greenlaw, D., J. Hatzius, A. K. Kashyap, and H. S. Shin (2008): "Leveraged losses: lessons from the mortgage market meltdown," in Proceedings of the US monetary policy forum, $7-59$.

Gunther, J. W. And R. R. Moore (2003): "Loss underreporting and the auditing role of bank exams," Journal of Financial Intermediation, 12, 153-177.

Hanson, S. G., A. K. Kashyap, And J. C. Stein (2011): "A macroprudential approach to financial regulation," Journal of economic Perspectives, 25, 3-28. 
Hirtle, B., A. Kovner, And M. Plosser (2016): "The impact of supervision on bank performance," Unpublished Working Paper.

Hovakimian, A. AND E. J. KAnE (2000): "Effectiveness of capital regulation at US commercial banks, 1985 to 1994," the Journal of Finance, 55, 451-468.

Huizinga, H. AND L. LAeven (2012): "Bank valuation and accounting discretion during a financial crisis," Journal of Financial Economics, 106, 614-634.

JAMES, C. (1991): "The losses realized in bank failures," The Journal of Finance, 46, $1223-1242$.

Matvos, G. And A. Seru (2014): "Resource allocation within firms and financial market dislocation: Evidence from diversified conglomerates," The Review of Financial Studies, 27, 1143-1189.

Mian, A. And A. Sufi (2009): "The consequences of mortgage credit expansion: Evidence from the US mortgage default crisis," The Quarterly Journal of Economics, 124, 1449-1496.

(2010): "Household Leverage and the Recession of 2007-09," IMF Economic Review, $58,74-117$.

NG, J. And T. O. Rusticus (2011): "Banks' Survival during the Financial Crisis: The Role of Financial Reporting Transparency," Unpublished Working Paper.

Nicoletti, A. K. (2016): "The effects of auditors and regulators on bank financial reporting: Evidence from loan loss provisions," Unpublished Working Paper.

Parlatore, C. (2015): "Transparency and bank runs," Unpublished Working Paper.

Peek, J., E. S. Rosengren, And G. M. Tootell (1999): "Is bank supervision central to central banking?" The Quarterly Journal of Economics, 114, 629-653.

REZENDE, M. (2016): "The effects of bank charter switching on supervisory ratings," Unpublished Working Paper.

RicE, S. C. And D. P. Weber (2012): "How effective is internal control reporting under SOX 404? Determinants of the (non-) disclosure of existing material weaknesses," Journal of Accounting Research, 50, 811-843.

Skinner, D. J. (2008): "The rise of deferred tax assets in Japan: The role of deferred tax accounting in the Japanese banking crisis," Journal of Accounting and Economics, 46, $218-239$.

Srinivasan, S., A. S. Wahid, And G. Yu (2014): "Admitting mistakes: Home country effect on the reliability of restatement reporting," The Accounting Review, 90, 1201-1240.

Tan, C. E. And S. M. Young (2015): "An analysis of "Little r" restatements," Accounting Horizons, 29, 667-693.

VYAS, D. (2011): "The Timeliness of Accounting Write-Downs by US Financial Institutions During the Financial Crisis of 2007-2008," Journal of accounting research, 49, 823-860. 
Table 1: Summary Statistics

This table presents descriptive statistics of the sample used in the analysis. Panel A reports summary statistics for the entire sample. Panel B reports summary statistics separately for state-chartered and federal-chartered banks. Panel C reports summary statistics concerning the catchup accounting restatements by type of restatement. Federal Regulator is an indicator variable that takes the value of one if the bank is chartered by the Office of the Comptroller of the Currency. Regulatory Leniency Index is our measure of regulatory leniency of the state regulator which is derived from the analysis in Agarwal et al. (2014) and is interpreted as the average difference between the federal regulator and each state regulator in the bank regulatory ratings assigned to the same bank. Total Assets is the total assets of a bank in \$000s (RCFD2170). Total Deposits is the total deposits held by a bank in $\$ 000$ s (RCON2200). Residential Loans/Total Loans is measured as the percentage of residential real estate loans (RCON1797+RCON5367+RCON5368) relative to total loans (RCFD2122). Commercial E Real Estate (CRE) Loans/Total Loans is measured as the percentage of commercial and real estate loans (RCON1415+RCON1460+RCON1480+RCFD2746) relative to total loans (RCFD2122). Consumer Loans/Total Loans is measured as the percentage of consumer loans (RCFDB538+RCFDB539+RCFD2011) relative to total loans (RCFD2122). Nonperforming Loans/Total Loans is defined as nonperforming loans (nonaccrual) (RCFD1403) and loans 90 days or more past due (RCFD1407) over total loans (RCFD2122). Other Real Estate Owned Ratio is defined as the ratio of other real estate owned and acquired in the process of obtaining possession of collateral (RCFD2150) divided by total assets (RCFD2170). Unused Commitment Ratio is defined as total unused commitments (RCFD3814 + RCFD3816 + RCFD3817 + RCFD3818 + RCFD6550 + RCFD3411) divided by total unused commitments and total loans. Well Capitalized is an indicator variable if the Tier 1 Capital Ratio (RCON7204) of the bank is above the well-capitalized threshold as defined by the FDIC. Negative Restatement is an indicator variable that takes the value of one if the bank makes a negative restatement (RIADB507) on its prior years' Reports of Condition and Income due to corrections of material accounting errors and changes in accounting principles. Positive Restatement is an indicator variable that takes the value of one if the bank makes a positive restatement (RIADB507) on its prior years' Reports of Condition and Income due to corrections of material accounting errors and changes in accounting principles. Error Restatements are restatements of prior years' Reports of Condition and Income (RIADB507) that are associated with mathematical or rounding errors. Principle Restatements are restatements of prior years' Reports of Condition and Income (RIADB507) that are associated with changes in accounting principles. Audit Restatements are restatements of prior years' Reports of Condition and Income (RIADB507) that are associated with the action of auditors. Tax Restatements are restatements of prior years' Reports of Condition and Income (RIADB507) that are associated with tax-related issues. Loan Loss Accounting Restatements are restatements of prior years' Reports of Condition and Income (RIADB507) that are associated with loan loss accounting errors. Securities Portfolio Restatements are restatements of prior years' Reports of Condition and Income (RIADB507) that are associated with accounting errors in the securities and investment portfolio of the bank. Noncurrent Items Restatements are restatements of prior years' Reports of Condition and Income (RIADB507) that are associated with accounting errors in the valuation of noncurrent balance sheet items. Consolidation Accounting Restatements are restatements of prior years' Reports of Condition and Income (RIADB507) that are associated with accounting errors related to consolidation accounting. Accrual Accounting Restatements are restatements of prior years' Reports of Condition and Income (RIADB507)

that are associated with errors in accrual accounting.

Panel A: Summary Statistics

\begin{tabular}{lcccccc}
\hline \hline & $\mathrm{N}$ & Mean & St. Dev. & $\mathrm{p} 25$ & $\mathrm{p} 50$ & $\mathrm{p} 75$ \\
\hline Bank Characteristics & & & & & & \\
\hline Federal Regulator & 310,500 & 0.226 & 0.418 & 0.000 & 0.000 & 0.000 \\
Regulatory Leniency Index & 310,500 & 0.076 & 0.062 & 0.000 & 0.084 & 0.116 \\
Total Assets & 310,500 & $1,139,067$ & $21,060,706$ & 54,765 & 113,812 & 259,178 \\
Total Deposits & 310,500 & 753,350 & $12,789,006$ & 45,566 & 94,228 & 211,609 \\
\hline Loan Compositions & & & & & & \\
\hline Residential Loans/Total Loans & 310,500 & 0.280 & 0.188 & 0.143 & 0.247 & 0.374 \\
Commercial \& Real Estate (CRE) Loans/Total Loans & 310,500 & 0.324 & 0.217 & 0.144 & 0.295 & 0.477 \\
Consumer Loans/Total Loans & 310,500 & 0.092 & 0.110 & 0.027 & 0.063 & 0.120 \\
Nonperforming Loans/Total Loans & 310,500 & 0.014 & 0.025 & 0.002 & 0.007 & 0.017 \\
Other Real Estate Owned Ratio & 310,500 & 0.003 & 0.008 & 0.000 & 0.000 & 0.002 \\
Unused Commitment Ratio & 310,500 & 0.129 & 0.083 & 0.072 & 0.118 & 0.172 \\
Well Capitalized & 310,500 & 0.994 & 0.077 & 1.000 & 1.000 & 1.000 \\
\hline Types of Restatements & & & & & & \\
\hline Negative Restatement & 310,500 & 0.032 & 0.175 & 0.000 & 0.000 & 0.000 \\
Positive Restatement & 310,500 & 0.020 & 0.140 & 0.000 & 0.000 & 0.000 \\
\hline \hline
\end{tabular}

This article is protected by copyright. All rights reserved. 
Panel B: Summary Statistics of State-Chartered Banks and Federal-Chartered Banks

\begin{tabular}{|c|c|c|c|c|c|c|}
\hline & $\mathrm{N}$ & Mean & St. Dev. & p25 & $\mathrm{p} 50$ & $\mathrm{p} 75$ \\
\hline \multicolumn{7}{|l|}{ State-Chartered Banks } \\
\hline Regulatory Leniency Index & 240,204 & 0.098 & 0.053 & 0.067 & 0.099 & 0.123 \\
\hline Total Assets & 240,204 & 572,739 & $6,421,740$ & 51,895 & 107,754 & 245,986 \\
\hline Total Deposits & 240,204 & 404,850 & $3,780,277$ & 43,151 & 89,510 & 201,059 \\
\hline Residential Loans/Total Loans & 240,204 & 0.283 & 0.192 & 0.144 & 0.248 & 0.377 \\
\hline Commercial \& Real Estate (CRE) Loans/Total Loans & 240,204 & 0.326 & 0.221 & 0.139 & 0.295 & 0.484 \\
\hline Consumer Loans/Total Loans & 240,204 & 0.088 & 0.104 & 0.025 & 0.06 & 0.115 \\
\hline Nonperforming Loans/Total Loans & 240,204 & 0.014 & 0.026 & 0.001 & 0.007 & 0.017 \\
\hline Other Real Estate Owned Ratio & 240,204 & 0.003 & 0.008 & 0.000 & 0.000 & 0.002 \\
\hline Unused Commitment Ratio & 240,204 & 0.127 & 0.081 & 0.071 & 0.116 & 0.169 \\
\hline Well Capitalized & 240,404 & 0.995 & 0.077 & 1 & 1 & 1 \\
\hline Negative Restatement & 240,204 & 0.032 & 0.177 & 0.000 & 0.000 & 0.000 \\
\hline Positive Restatement & 240,204 & 0.021 & 0.143 & 0.000 & 0.000 & 0.000 \\
\hline \multicolumn{7}{|l|}{ Federal-Chartered Banks } \\
\hline Regulatory Leniency Index & 70,296 & 0 & 0 & 0 & 0 & 0 \\
\hline Total Assets & 70,296 & $3,074,231$ & $42,584,692$ & 66,492 & 136,575 & 309,187 \\
\hline Total Deposits & 70,296 & $1,944,188$ & $25,918,870$ & 54,933 & 112,555 & 249,503 \\
\hline Residential Loans/Total Loans & 70,296 & 0.268 & 0.171 & 0.141 & 0.245 & 0.365 \\
\hline Commercial \& Real Estate (CRE) Loans/Total Loans & 70,296 & 0.319 & 0.203 & 0.157 & 0.294 & 0.452 \\
\hline Consumer Loans/Total Loans & 70,296 & 0.107 & 0.126 & 0.035 & 0.073 & 0.135 \\
\hline Nonperforming Loans/Total Loans & 70,296 & 0.013 & 0.022 & 0.002 & 0.007 & 0.016 \\
\hline Other Real Estate Owned Ratio & 70,296 & 0.002 & 0.006 & 0.000 & 0.000 & 0.002 \\
\hline Unused Commitment Ratio & 70,296 & 0.135 & 0.088 & 0.075 & 0.123 & 0.179 \\
\hline Well Capitalized & 70,296 & 0.995 & 0.069 & 1 & 1 & 1 \\
\hline Negative Restatement & 70,296 & 0.029 & 0.167 & 0.000 & 0.000 & 0.000 \\
\hline Positive Restatement & 70,296 & 0.018 & 0.132 & 0.000 & 0.000 & 0.000 \\
\hline
\end{tabular}

Panel C: Summary Statistics of Restatements by Type

\begin{tabular}{lccc}
\hline \hline & \% Restatements & Share Neg. Restatements & \% Risk-Weighted Assets \\
\hline Error Restatements & 1.90 & 43.26 & -0.02 \\
Principle Restatements & 24.30 & 81.64 & -0.15 \\
Audit Restatements & 9.96 & 50.83 & -0.20 \\
Tax Restatements & 25.25 & 50.19 & -0.21 \\
Other Accrual Accounting Restatements & 37.86 & 60.72 & -0.22 \\
Loan Loss Accounting Restatements & 0.86 & 68.72 & -0.67 \\
Securities Portfolio Restatements & 2.66 & 59.37 & -0.24 \\
Noncurrent Items Restatements & 5.31 & 52.79 & -0.17 \\
Consolidation Accounting Restatements & 2.26 & 45.07 & -0.13 \\
\hline \hline
\end{tabular}

This article is protected by copyright. All rights reserved. 


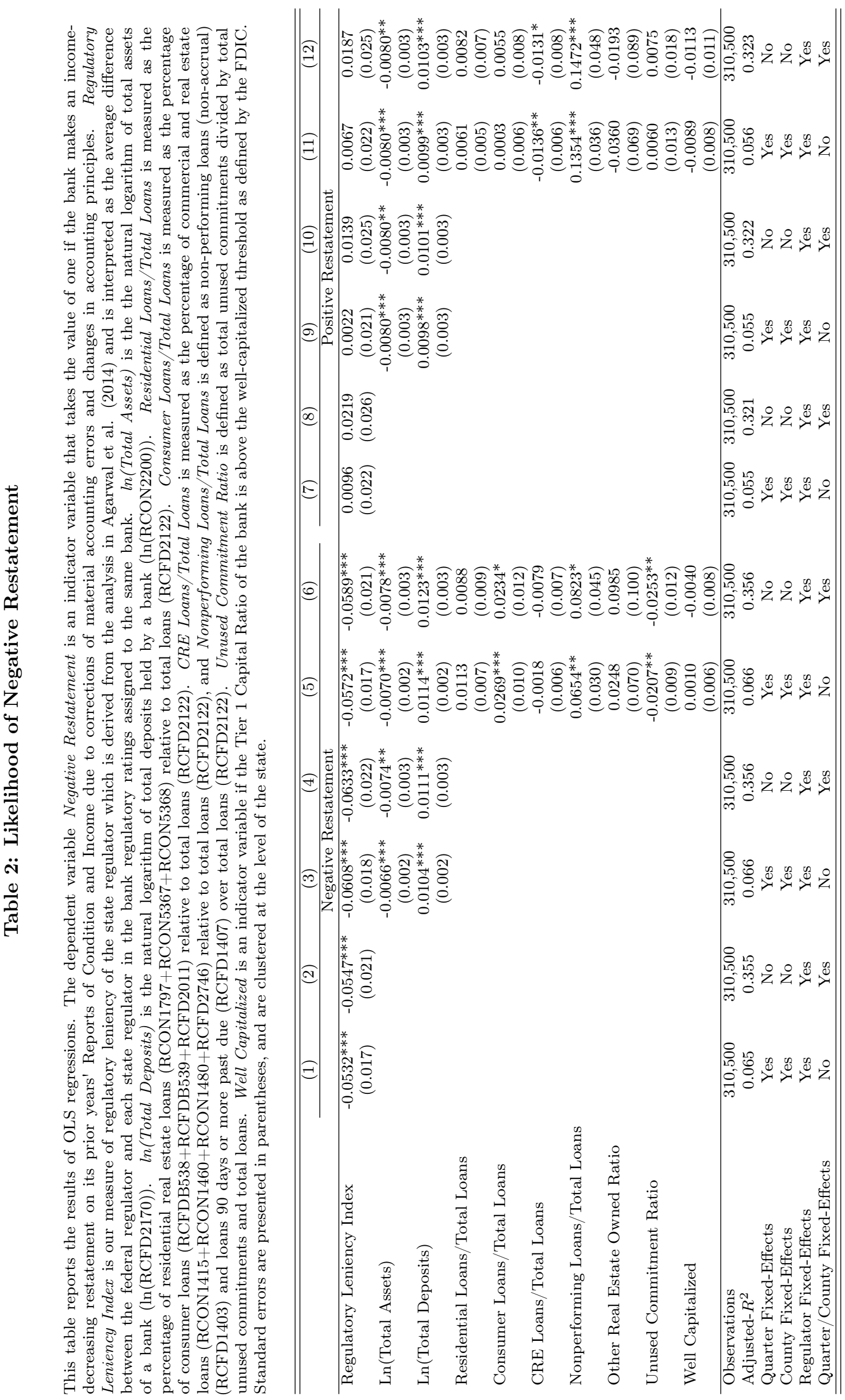

35

This article is protected by copyright. All rights reserved. 


\section{Table 3: Likelihood of Negative Restatement: Timing Analysis}

This table reports the results of OLS regressions. The dependent variable Negative Restatement is an indicator variable that takes the value of one if the bank makes an income-decreasing restatement on its prior years' Reports of Condition and Income due to corrections of material accounting errors and changes in accounting principles. Regulatory Leniency Index is our measure of regulatory leniency of the state regulator which is derived from the analysis in Agarwal et al. (2014) and is interpreted as the average difference between the federal regulator and each state regulator in the bank regulatory ratings assigned to the same bank. Past TED Spread and Future TED Spread are the average TED spreads over the past and subsequent four quarters, respectively. Past HPI Change and Future HPI Change are the House Price Index (HPI) growth rates in the bank's branch service area over the past and subsequent four quarters, respectively. The HPI change is calculated using the all-transactions indexes at the MSA and state non-metropolitan levels provided by the Federal Housing Finance Agency. We calculate the HPI change for each bank by weighting the HPI change variable for each bank by the percentage of deposits of the bank. Other controls include Ln(Total Assets), Ln(Total Deposits), Residential Loans/Total Loans, Consumer Loans/Total Loans, CRE Loans/Total Loans, Nonperforming Loans/Total Loans, Other Real Estate Owned Ratio, Unused Commitment Ratio, and Well Capitalized. All specifications include Quarter/County Fixed-Effects and Regulator Fixed-Effects. Standard errors are presented in parentheses, and are clustered at the level of the state.

\begin{tabular}{|c|c|c|c|c|}
\hline & (1) & $(2)$ & $(3)$ & (4) \\
\hline & \multicolumn{4}{|c|}{ Negative Restatement } \\
\hline Regulatory Leniency Index & $\begin{array}{c}-0.0589^{* * *} \\
(0.021)\end{array}$ & $\begin{array}{c}-0.0589^{* * *} \\
(0.021)\end{array}$ & $\begin{array}{c}-0.0577^{* * *} \\
(0.022)\end{array}$ & $\begin{array}{c}-0.0598^{* * *} \\
(0.022)\end{array}$ \\
\hline Regulatory Leniency Index $\times$ Future TED Spread & $\begin{array}{c}-0.0370^{* *} \\
(0.015)\end{array}$ & & & \\
\hline Regulatory Leniency Index $\times$ Past TED Spread & & $\begin{array}{r}-0.0103 \\
(0.009)\end{array}$ & & \\
\hline Future HPI Change & & & $\begin{array}{c}-0.0163^{*} \\
(0.009)\end{array}$ & \\
\hline Regulatory Leniency Index $\times$ Future HPI Change & & & $\begin{array}{c}0.0342^{*} \\
(0.018)\end{array}$ & \\
\hline Past HPI Change & & & & $\begin{array}{c}-0.0069 \\
(0.008)\end{array}$ \\
\hline Regulatory Leniency Index $\times$ Past HPI Change & & & & $\begin{array}{c}0.0292 \\
(0.019)\end{array}$ \\
\hline Observations & 310,500 & 310,500 & 309,038 & 309,038 \\
\hline Adjusted- $R^{2}$ & 0.356 & 0.356 & 0.357 & 0.357 \\
\hline Controls & Yes & Yes & Yes & Yes \\
\hline Regulator Fixed-Effects & Yes & Yes & Yes & Yes \\
\hline Quarter/County Fixed-Effects & Yes & Yes & Yes & Yes \\
\hline
\end{tabular}

This article is protected by copyright. All rights reserved. 


\section{Table 4: Likelihood of Call Report Amendment}

This table reports the results of OLS regressions. The dependent variable Amendment which is an indicator variable that takes the value of one if the last time stamp on each individual call report exceeds the corresponding call report deadline by $n$ days, where $n=\{15,45\}$. Regulatory Leniency Index is our measure of regulatory leniency of the state regulator which is derived from the analysis in Agarwal et al. (2014) and is interpreted as the average difference between the federal regulator and each state regulator in the bank regulatory ratings assigned to the same bank. $\ln$ (Total Assets) is the the natural logarithm of total assets of a bank ( $\ln (\mathrm{RCFD} 2170))$. $\ln ($ Total Deposits) is the natural logarithm of total deposits held by a bank $(\ln (\mathrm{RCON} 2200))$. Residential Loans/Total Loans is measured as the percentage of residential real estate loans (RCON1797+RCON5367+RCON5368) relative to total loans (RCFD2122). Consumer Loans/Total Loans is measured as the percentage of consumer loans (RCFDB538+RCFDB539+RCFD2011) relative to total loans (RCFD2122). CRE Loans/Total Loans is measured as the percentage of commercial and real estate loans (RCON1415+RCON1460+RCON1480+RCFD2746) relative to total loans (RCFD2122), and Nonperforming Loans/Total Loans is defined as non-performing loans (non-accrual) (RCFD1403) and loans 90 days or more past due (RCFD1407) over total loans (RCFD2122). Unused Commitment Ratio is defined as total unused commitments divided by total unused commitments and total loans. Well Capitalized is an indicator variable if the Tier 1 Capital Ratio of the bank is above the well-capitalized threshold as defined by the FDIC. All specifications include Quarter/County Fixed-Effects and Regulator Fixed-Effects. Standard errors are presented in parentheses and are clustered at the level of the state.

\begin{tabular}{lcccc}
\hline \hline & $(1)$ & $(2)$ & $(3)$ & $(4)$ \\
& \multicolumn{4}{c}{ Amendment } \\
\hline Regulatory Leniency Index & $-0.1262^{* *}$ & $-0.1108^{*}$ & $-0.0972^{*}$ & -0.0873 \\
Ln(Total Assets) & $(0.053)$ & $(0.062)$ & $(0.051)$ & $(0.060)$ \\
& $0.0353^{* * *}$ & $0.0327^{* * *}$ & $0.0265^{* * *}$ & $0.0242^{* * *}$ \\
Ln(Total Deposits) & $(0.006)$ & $(0.007)$ & $(0.006)$ & $(0.007)$ \\
& $0.0120^{* *}$ & $0.0142^{* *}$ & $0.0107^{*}$ & $0.0128^{*}$ \\
Residential Loans/Total Loans & $(0.006)$ & $(0.007)$ & $(0.006)$ & $(0.007)$ \\
& $-0.0329^{*}$ & -0.0270 & -0.0239 & -0.0204 \\
Consumer Loans/Total Loans & $(0.017)$ & $(0.020)$ & $(0.016)$ & $(0.020)$ \\
& $-0.0512^{*}$ & -0.0476 & -0.0335 & -0.0316 \\
CRE Loans/Total Loans & $(0.027)$ & $(0.033)$ & $(0.025)$ & $(0.030)$ \\
& $0.0518^{* * *}$ & $0.0559^{* *}$ & $0.0376^{* *}$ & $0.0379^{*}$ \\
Nonperforming Loans/Total Loans & $(0.018)$ & $(0.023)$ & $(0.017)$ & $(0.021)$ \\
& $0.6397^{* * *}$ & $0.5687^{* *}$ & $0.5411^{* * *}$ & $0.4815^{* *}$ \\
Other Real Estate Owned Ratio & $(0.193)$ & $(0.242)$ & $(0.172)$ & $(0.217)$ \\
& $1.2068^{* * *}$ & $1.0885^{* *}$ & $0.8944^{* * *}$ & $0.8431^{*}$ \\
Unused Commitment Ratio & $(0.302)$ & $(0.434)$ & $(0.293)$ & $(0.438)$ \\
& 0.0180 & 0.0317 & 0.0275 & 0.0397 \\
Well Capitalized & $(0.029)$ & $(0.035)$ & $(0.026)$ & $(0.033)$ \\
& 0.0036 & -0.0131 & 0.0122 & -0.0006 \\
Observations & $(0.019)$ & $(0.027)$ & $(0.019)$ & $(0.028)$ \\
Adjusted- $R^{2}$ & 163,255 & 163,255 & 163,255 & 163,255 \\
Number of late days & 0.124 & 0.371 & 0.105 & 0.355 \\
Quarter Fixed-Effects & Yes & No & Yes & No \\
County Fixed-Effects & $>15$ days & $>45$ days & $>45$ days \\
Regulator Fixed-Effects & No & Yes & Yes & No \\
Quarter/County Fixed-Effects & Yes & No & Yes \\
\hline \hline
\end{tabular}

This article is protected by copyright. All rights reserved. 


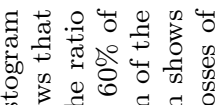

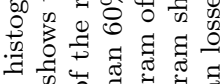

ज虫

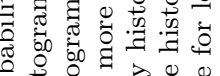

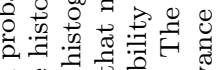

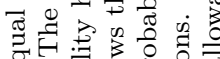

สี

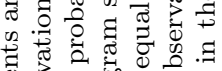

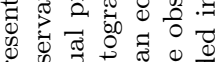

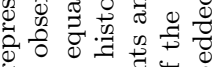

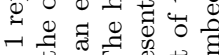

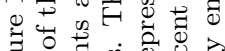

占

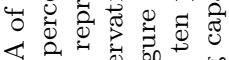

《可

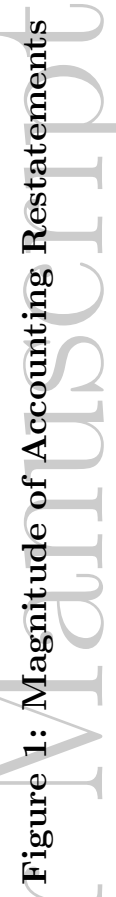

तै

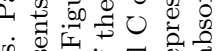

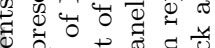

:

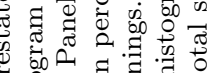

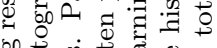

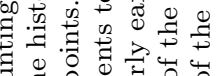

言

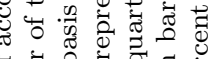

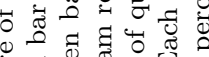

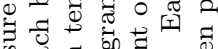

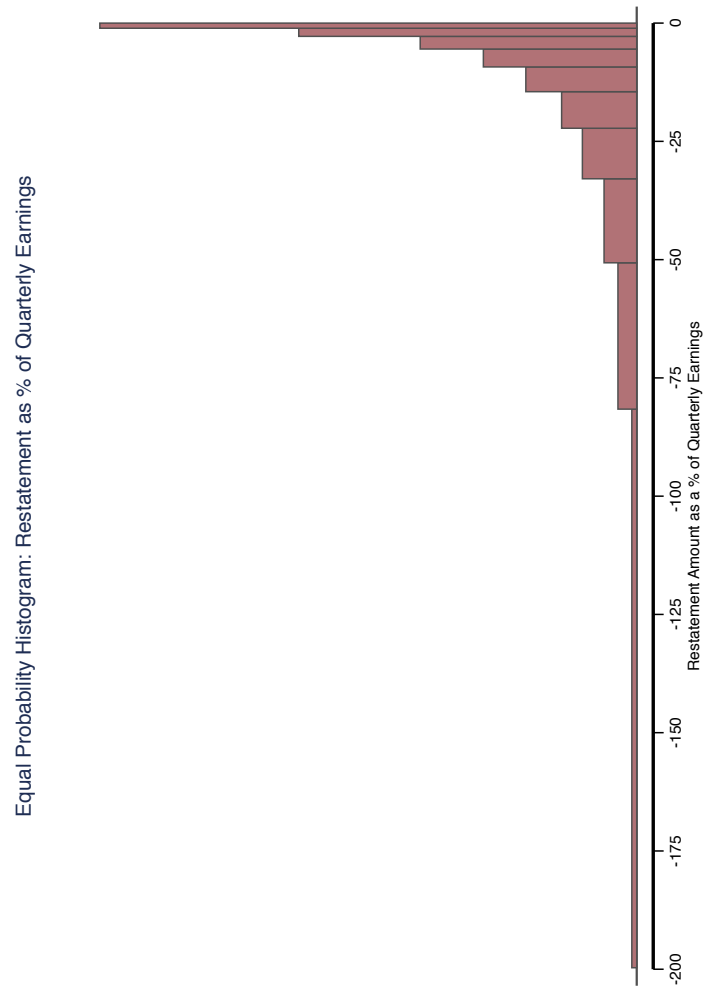

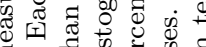

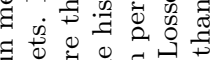

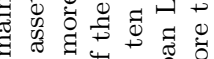

च च

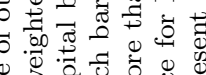

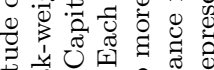

䓛

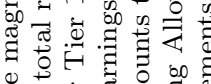

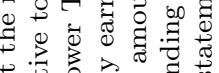

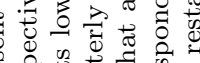

की

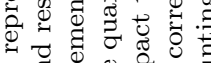

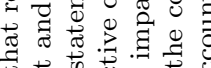

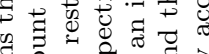

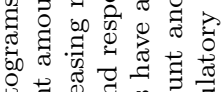

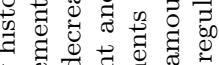

它讨

焉

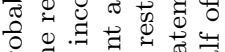

西

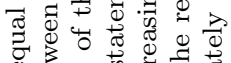

$\Phi$ bo

용 0

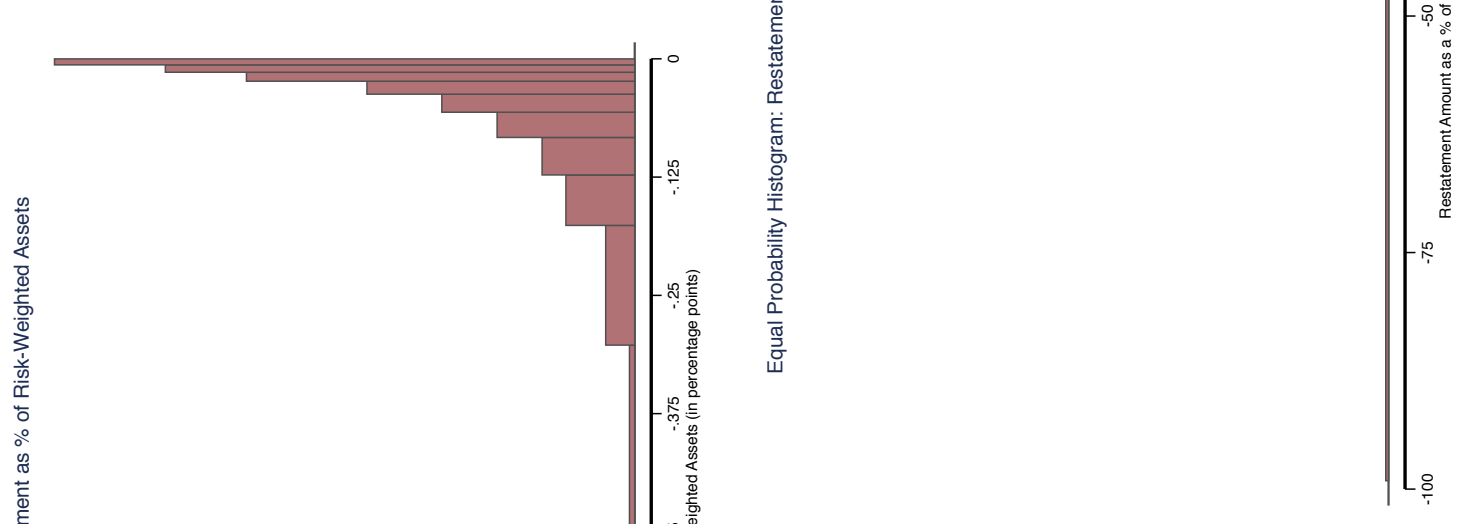

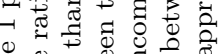

品

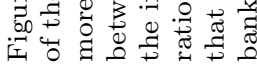

This article is protected by copyright. All rights reserved. 


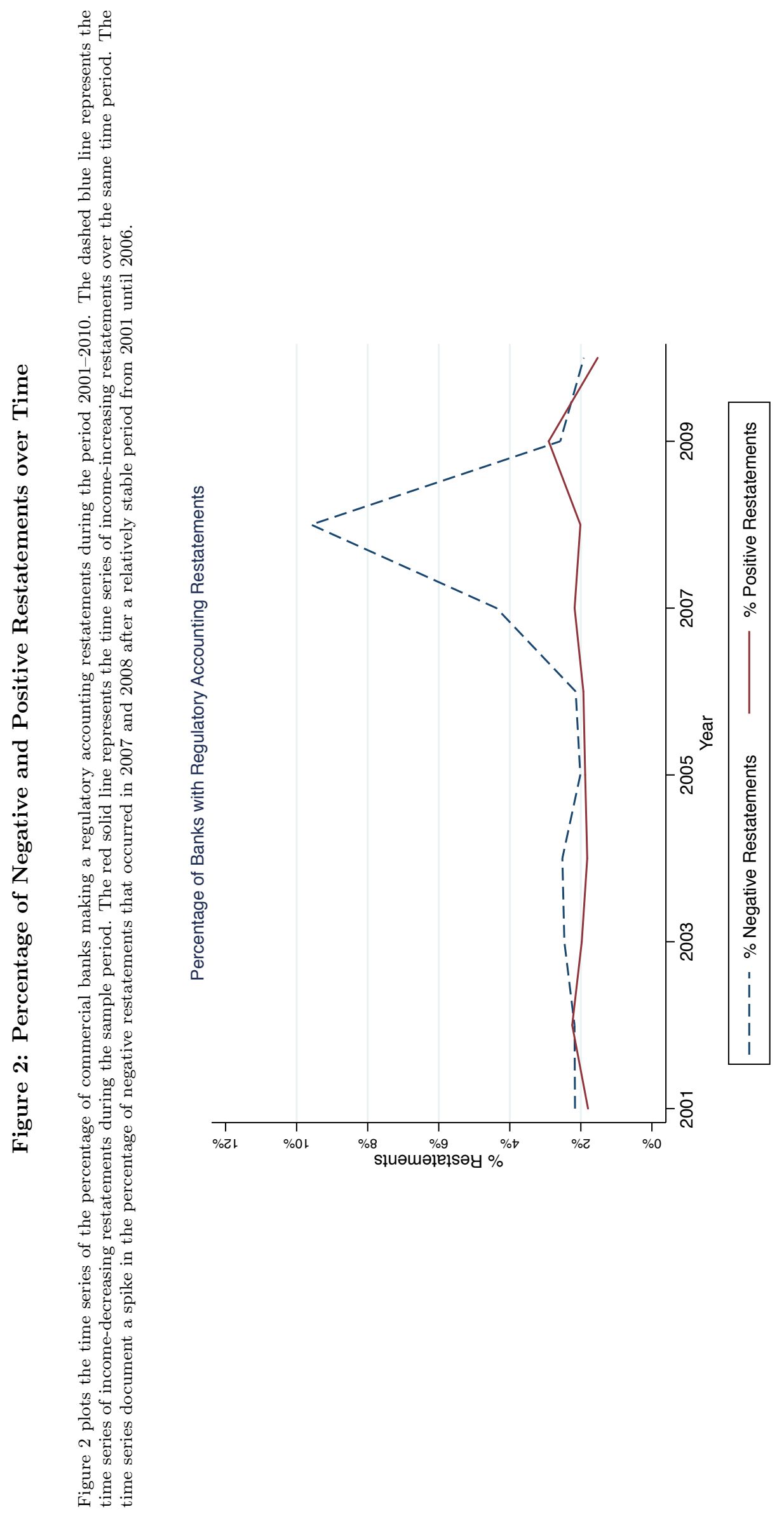

39

This article is protected by copyright. All rights reserved. 


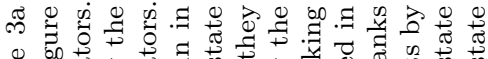

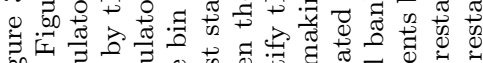

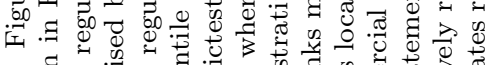

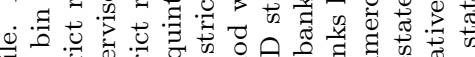

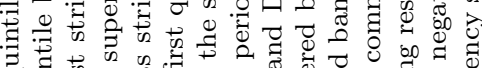

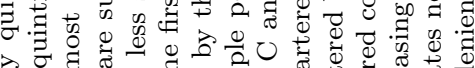

它

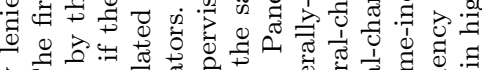

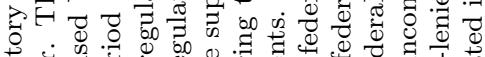

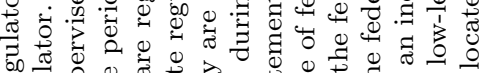

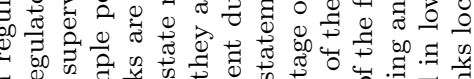

仓) $\quad \begin{gathered}0 \\ 0\end{gathered}$

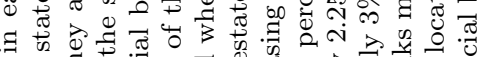

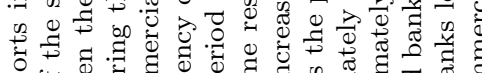

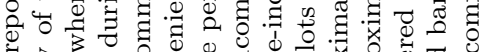

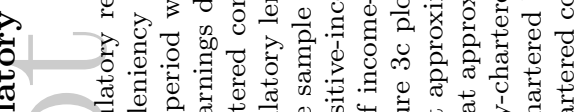

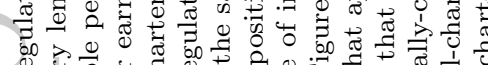

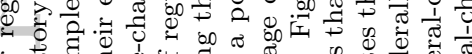

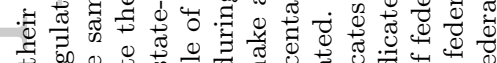

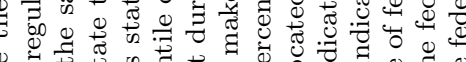

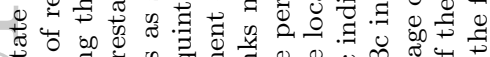

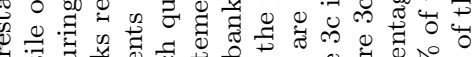

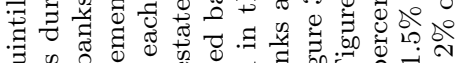

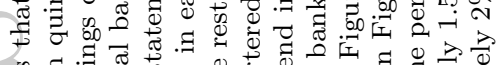

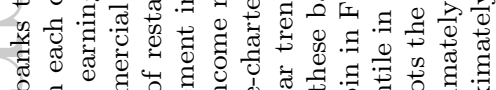

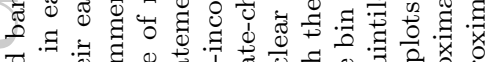

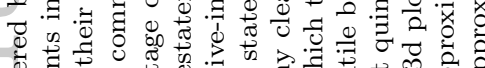
ए

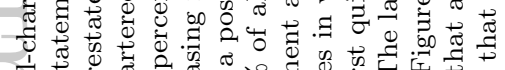

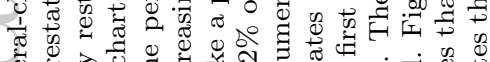

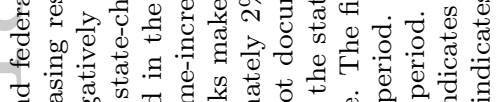
สี

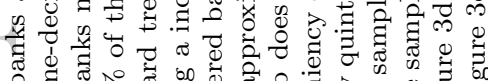

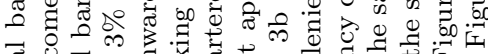
西记

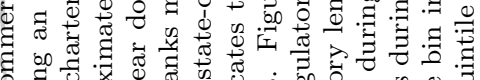

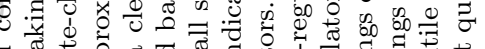

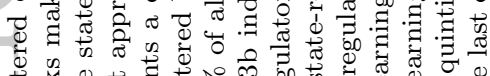

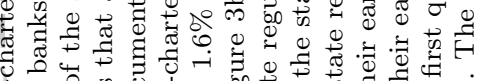

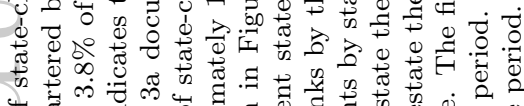

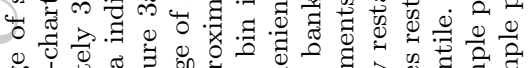
so

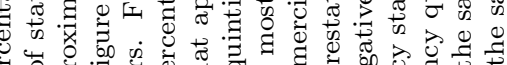

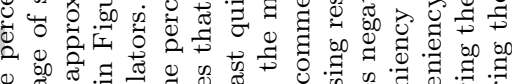

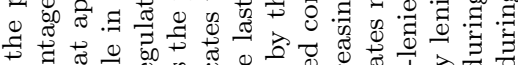

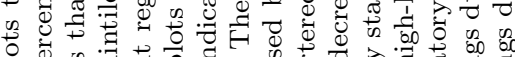
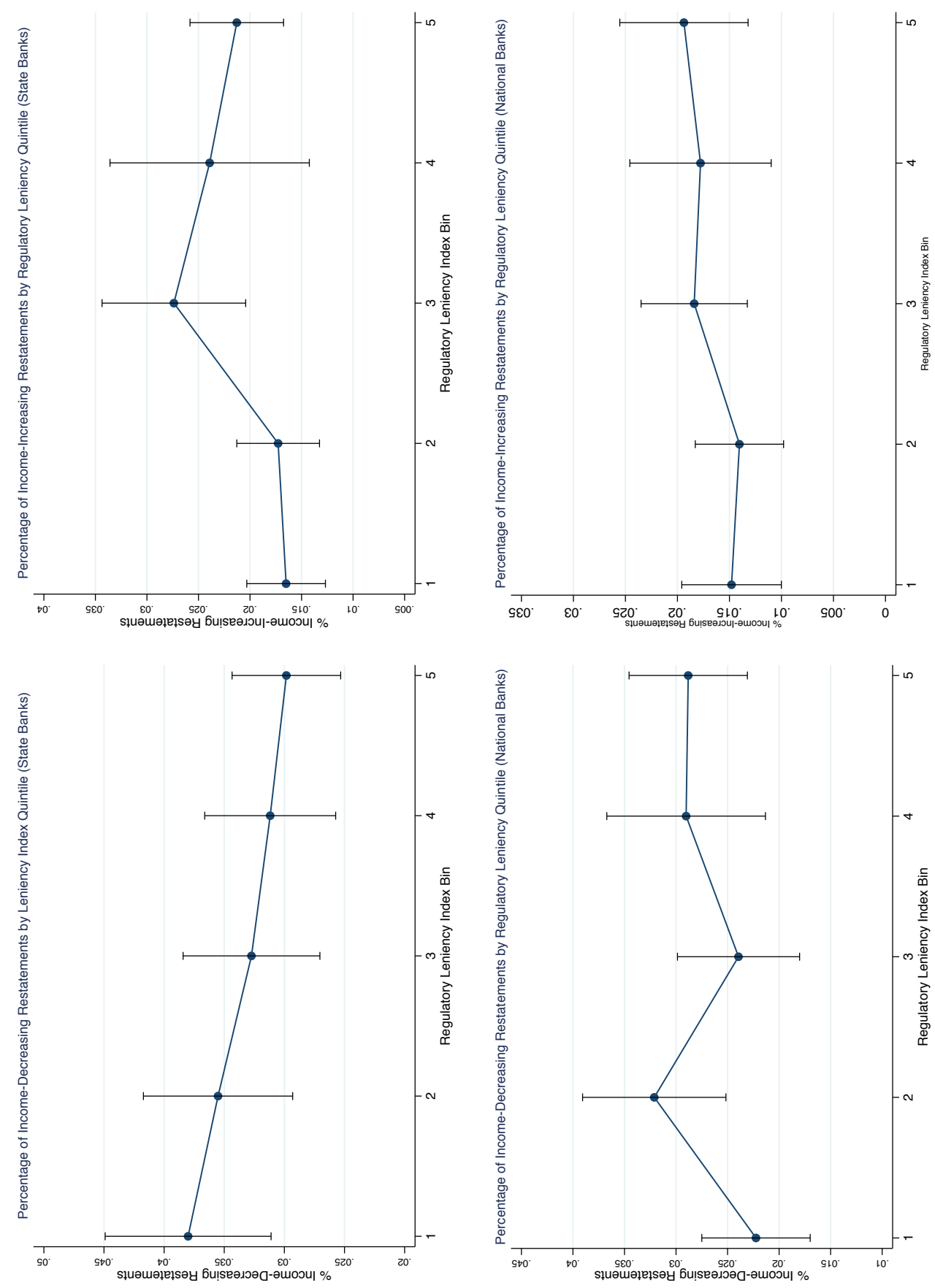

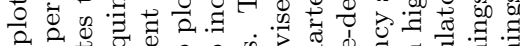

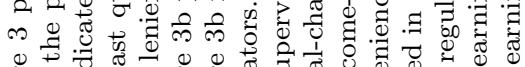

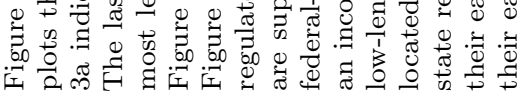

This article is protected by copyright. All rights reserved. 


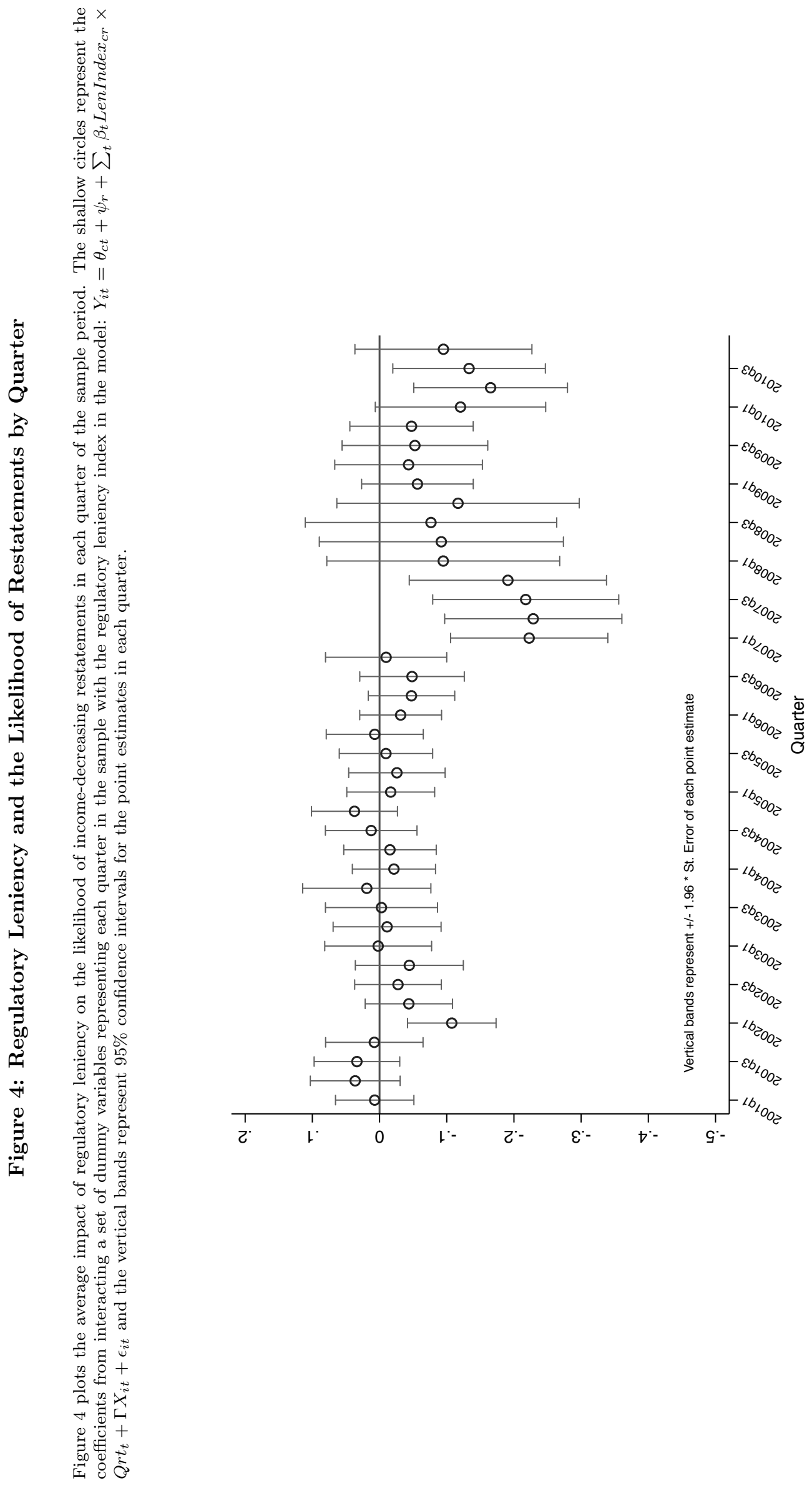

This article is protected by copyright. All rights reserved. 

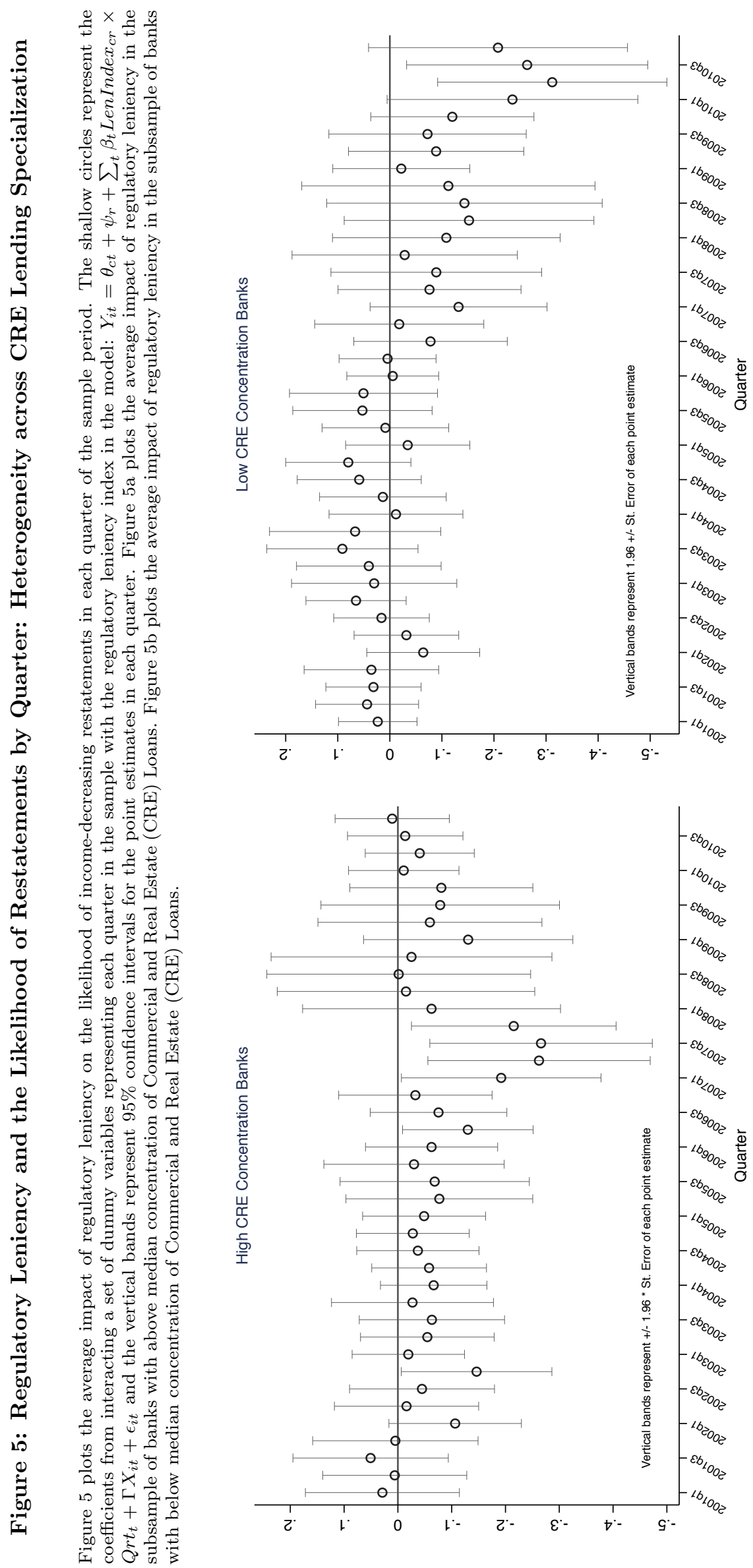

42

This article is protected by copyright. All rights reserved. 


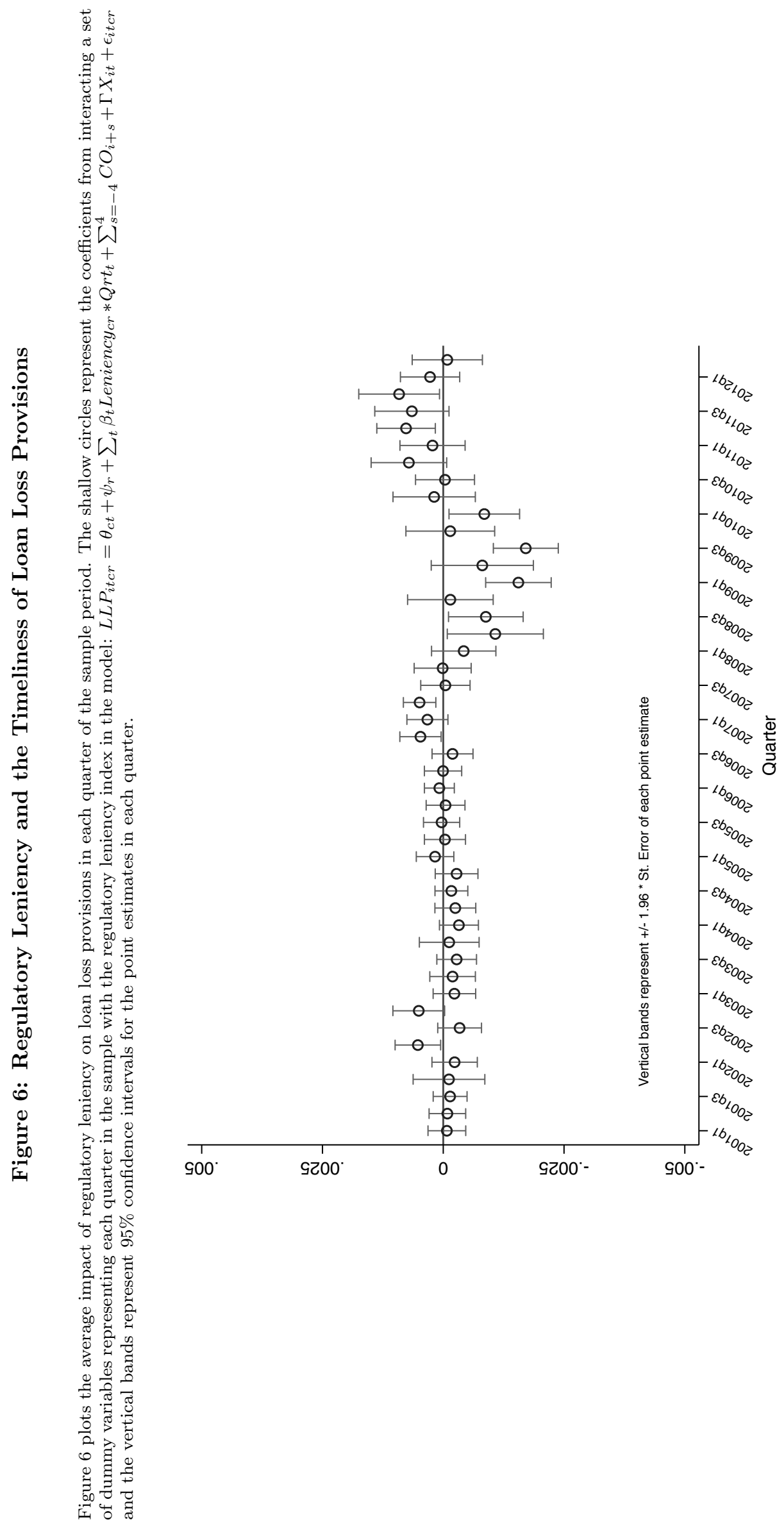

43

This article is protected by copyright. All rights reserved. 